


$$
\frac{1}{1}
$$


NTL SB $470.05 A 5$ Vol. I 



\section{FORTY YEARS OF \\ LANDSCAPE ARCHITECTURE}

BEING THE PROFESSIONAL PAPERS OF

FREDERICK LAW OLMSTED, SENIOR 
Digitized by the Internet Archive in 2011 with funding from LYRASIS members and Sloan Foundation 



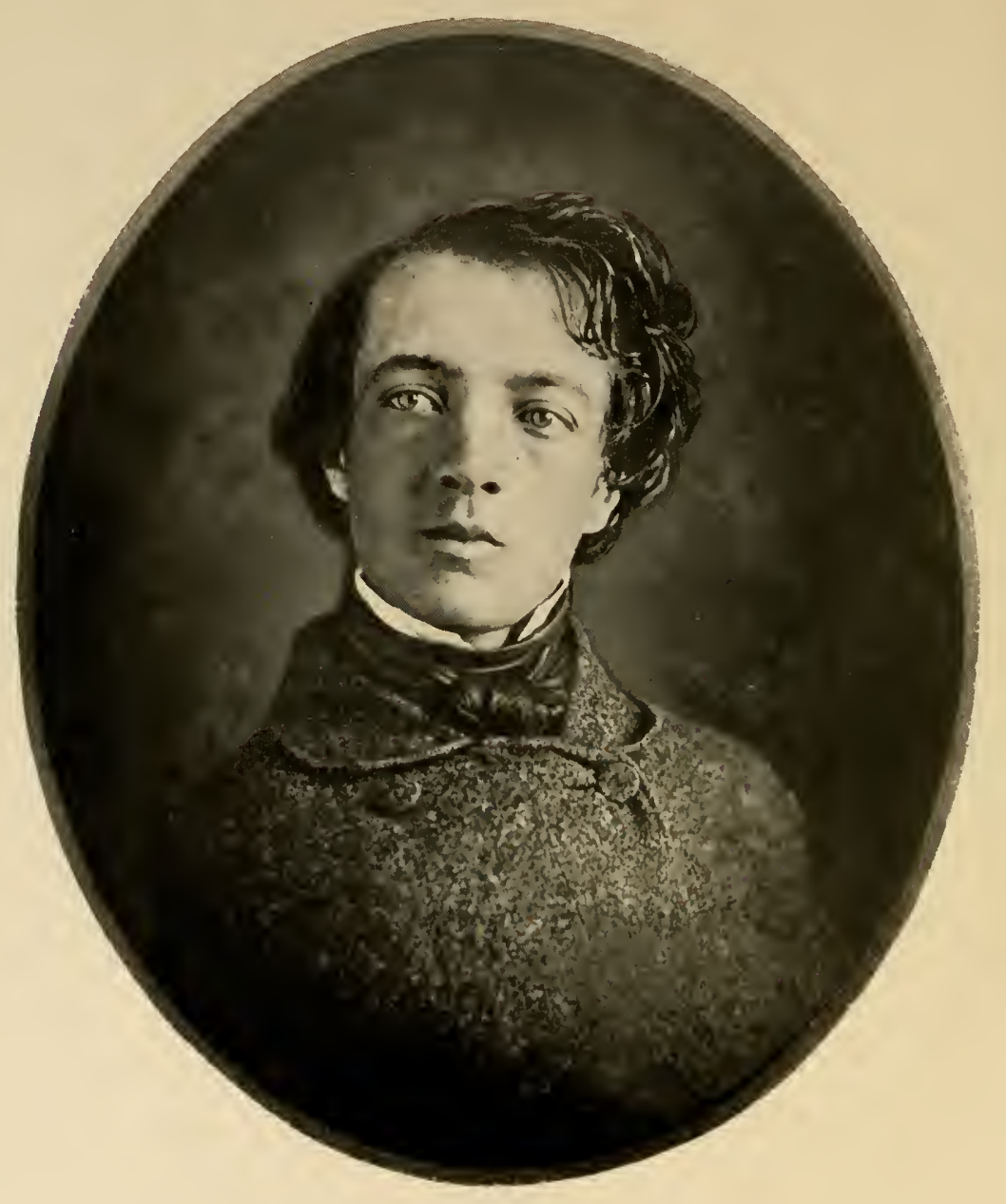

Frederick Law Olmsted in $\mathbf{I} 85^{\circ}$ 


\title{
FREDERICK LAW OLMSTED
}

\section{LANDSCAPE ARCHITECT}

\author{
I 822-1903
}

\author{
EDITED BY \\ FREDERICK LAW OLMSTED, JR. \\ AND
}

THEODORA KIMBALL

\section{$\star$ \\ EARLY YEARS AND EXPERIENCES}

TOGETHER WITH BIOGRAPHICAL NOTES

ILLUSTRATED

G. P. PUTNAM'S SONS NEW YORK AND LONDON Tbe Tknickerbocker $\mathbb{D r e s g}$

I 922 


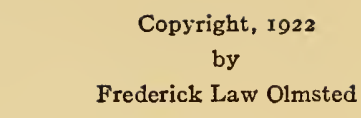

Made in the United States of America

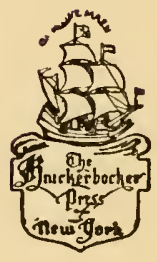


ON THE CENTENNIAL YEAR OF HIS BIRTH IS PUBLISHED THIS FIRST VOLUME OF THE PROFESSIONAL PAPERS OF FREDERICK LAW OLMSTED 



\section{PREFACE}

THE richness and variety of the professional papers left by Frederick Law Olmsted, Senior, is astonishing, especially in view of the enormous amount of work on the ground which he accomplished in the almost forty years of his active career as a Landscape Architect. Orderly and thorough by habit of thought, he wrote down with minute care the various steps of his professional dealings, in many cases retaining unused drafts which show valuable processes of mind. From the beginning he realized fully the importance of presenting the new profession to the public in a favorable light, and was constantly "coming before the public,"-as the phrase went, -in the daily press and in occasional pamphlets. Several of his professional reports also were printed at his own expense, but a far greater number have lain buried in the files of Park Department Documents or have never been printed in any form. His personal life after 1857 was so closely bound up with his professional activities that his family and friendly letters reveal many sidelights on his work. The record of his professional correspondence is fortunately full. When the political harassments to which he was subjected prevented him from sleeping, he used to while away the hours of the night by writing, sometimes in regard to his current problems and sometimes bits of general wisdom gained in his professional experience. About 1890 when he was obliged in some degree to lessen his travelling about, he wrote several long retrospective letters, reviewing his career, and he left also two or three short fragments of autobiography, which are included in this present volume.

Among the many people outside the Olmsted family who had preserved and were able to return letters for editorial purposes, there should be especially mentioned: the late Frederick J. Kingsbury of Waterbury, Conn., who added to the letters a valuable group of reminiscences; Miss Emma Brace (letters to her father Charles Loring Brace) who assisted also in the preliminary sorting of Olmsted letters; Miss 
Sarah Norton (letters to her father Charles Eliot Norton); and the Vaux family, who have aided the editors of Mr. Olmsted's papers in every possible way, Mr. Bowyer Vaux especially, and given permission for the publication in Vol. Two of several very illuminating letters from Calvert Vaux to $\mathrm{Mr}$. Olmsted, in $\mathbf{1 8 6 4 - 6 5}$, which formed a turning point in the latter's career.

The present volume of Mr. Olmsted's papers is intended as an introduction to a series covering his main activities as a Landscape Architect. The writings are to be arranged by large groups, according to the nature of the works in connection with which they were written,-public parks and park systems, town plans, land subdivisions, grounds for public and semi-public buildings, private estates, and so on. This somewhat arbitrary rather than sequential arrangement is adopted perforce because Mr. Olmsted's writings-illuminating as they are in regard to principles of wide applicationrelate, with few exceptions, directly to some specific problem or set of conditions, dealing with the case now from the point of view of æsthetics, now from that of utility and convenience or economy, sometimes from that of the sociologist, sometimes from that of the administrator or that of the artisan.

Mr. Olmsted wrote not primarily to set forth general theories but to show how to get satisfactory results under actual specific circumstances and requirements as he found them, or to carry conviction of the wisdom of certain courses of action which he advised.

In this connection it is interesting to compare his professional writings with those of A. J. Downing,-whose friendship unquestionably did much to stimulate and develop $\mathrm{Mr}$. Olmsted's interest in landscape matters, and whose activities in the Central Park campaign and in bringing Calvert Vaux into relations with $\mathrm{Mr}$. Olmsted led the latter so unexpectedly into the profession. It is very striking to note the contrast between Downing's somewhat doctrinaire and a priori method of discussing landscape problems, and Mr. Olmsted's habitual method, which was frankly to envisage the peculiar facts of each situation as an individual problem to be solved on its own merits in its own individual way, and then to test and perhaps correct his conclusions by reasoning back to find principles consistent alike with the facts and artistic intuitions present in this particular case and with other principles 
and theories accepted by him as sound and true. He looked on theories and "principles" as valuable tools of service, inevitably incomplete and defective, frequently in need of reshaping, sharpening and improvement, and he was seldom tempted to overlook or minimize new and special factors in a problem merely because their recognition would force him to modify what he had come to regard as firmly established principles.

As a result of his method of writing Mr. Olmsted's published papers must necessarily be a somewhat disjointed compilation, passages of the greatest interest and value for their applicability to problems of residential property occurring in the discussion of a park problem and vice versa, points of detail in matters of technique sometimes coming cheek by jowl with discussions of fundamentally controlling purposes. It is proposed, however, to round out the series by a general volume which will weave together many fragments and extracts,-mainly from letters and reports not considered worthy of presentation in extenso in the previous volumes, together with connecting and explanatory matter by $\mathrm{F}$. L. Olmsted, Junior,-into an orderly and consistent presentation of the theory and practice of the landscape art as developed by Frederick Law Olmsted, Senior. This last volume is also to contain a full subject index to all the material in the whole series of volumes, thus opening for ready reference a mine of information on hundreds of topics in the field of landscape architecture and administration of public works.

While Volume One is devoted to the background of Mr. Olmsted's professional career, Volume Two will deal with his first professional undertaking, the New York Central Park, designed in coöperation with Calvert Vaux, which marks the beginning of a new era of parks and of civic design in America. On this account it has seemed desirable to give a much fuller presentation of Mr. Olmsted's papers relating to Central Park than can be given to any other single example of design. This is the more justifiable because many of the later park reports repeat and develop principles first stated in connection with Central Park.

Furthermore the history of Central Park is considered of such importance in the development of the City of New York that the Russell Sage Foundation, in connection with the survey of Greater New York and Environs, has made a special grant to enable the editors of the Olmsted Papers to 
produce a monograph on Central Park which shall not only present the Park from the standpoint of design, but shall also give a connected history of its conception, design, construction, and management up to the time of its fullest development before its principal designers lost touch with it in the 80 's. The volume will therefore offer not merely, or even primarily, Mr. Olmsted's personal contribution as a designer, but rather the conception of the park as he always regarded it,- -as a great collaborative effort in and for a democratic community.

The editorial work on the great mass of Mr. Olmsted's papers personal and professional was begun soon after his death by F. L. Olmsted, Junior. At this time, I903-04, the bulk of the papers was gone over and separated into the more and less important, and a beginning made on their arrangement, with the assistance of Mr. Philip P. Sharples. In the spring of $1920, \mathrm{Mr}$. F. L. Olmsted engaged the present editor's services to bring the material into definitive form for publication, while Mrs. Frederick Law Olmsted, Senior, was still alive to lend the aid of her memory to the work. During the summer and fall of 1920 Mrs. Olmsted, at ninety years of age, made it her major occupation, saw the scheme of the whole series of volumes take shape, and approved the selection of material for the first volume, in which she herself had perhaps the greatest personal interest. It was hoped that the first volume might appear on the hundredth anniversary of Mr. Olmsted's birth, April 26, I922, and that she might live to see it published. She died on April 23, I92 I, but not before she had helped the work immeasurably not only by her discriminating advice but by the inspiration of her interest.

The whole work has been subject to the direction, criticism, and approval of the present Mr. Frederick Law Olmsted, who has made the editorial work and publication possible, and has added some of the brief explanatory notes.

T. K.

BroOKLINE, July 28, 1922. 


\section{CONTENTS}

PART I

PAGE

BIOGRAPHICAL NOTES 1822-1903

\section{PART II}

EARLY EXPERIENCES: THEIR CONTRIBUTION TO HIS LATER CAREER

CHAPTER

I. Autobiographical Passages . . . . 43

II. Early Pleasure Tours . . . . 64

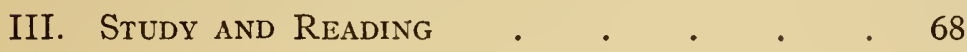

IV. FARMING . . . . . . . 75

V. Landscaping • . $\quad$. $\quad$. 84

VI. Relations with Downing . . . . 88

VII. LaNdSCAPE ObSERVATIONS From European TRAVEL . . . . . . . . . 94

VIII. SOUTHERN TRIPS, I 852-I854 • . . . I I I

IX. Reputation in I 857 . $\quad . \quad$. $\quad$ II

PART III

AMERICAN LANDSCAPE GARDENING IN 1857 • • I2I 



\section{ILLUSTRATIONS}

FACING

Frederick LaW Olmsted in I850 . . Frontispiece

The Five Friends in New Haven Days . . . 66

Charles Trask, Frederick J. Kingsbury, John Hull Olmsted, Charles Loring Brace, and Frederick Law Olmsted.

Facsimile of Letter with Mr. Olmsted's Earliest

SkETCH FOR IMPROVEMENT OF GroundS, I847 • • 84

Facsimile of Petition to Secure Appointment of Mr. Olmsted as Superintendent of Central Park, $\mathbf{I} 857$ • 



\section{LIST OF PAPERS AND DOCUMENTS}

A sequential list of the more important papers included in this volume. Matter previously printed is shown by italic type.

Autobiographical Fragments:

Passages in the Life of an Unpractical Man .

PAG E

Hints Aidful to Elementary Self-Education in Design

45

58

Selections from Letters to Members of Family and Boyhood Friends, 1845-185

Account by Mary Cleveland Perkins Olmsted of Life on Staten Island, and Meeting of Olmsted and Perkins Families .

Selection from Paper by John Charles Olmsted read before Boston Society of Landscape Architects, I916: The Influence of A. J. Downing upon the Designers of Central Park

Letter from F. L. Olmsted to Andrew Jackson Downing, I 850

Selections from Walks and Talks of an American Farmer in England, Edition of 1852 . . . . . .

Selection from $A$ Journey in Texas, Edition of 1857 , and $A$ Journey in the Back Country, Edition of 1860

Petition that F. L. Olmsted be Appointed Superintendent of the Central Park, I857, signed by Washington Irving and others facing

Letter from Asa Gray recommending F. L. Olmsted . I 20

Selection from Article by F. L. Olmsted on Parks, Appleton's New American Cyclopedia, I86I

A Letter from F. L. Olmsted to a Park Commissioner of Rochester, N. Y., I888, regarding the Status of Landscape Architecture in the United States 



\section{Frederick Law Olmsted}

Landscape Architect

\section{PART I. BIOGRAPHICAL NOTES}

1822-1903 



\section{PART I \\ BIOGRAPHICAL NOTES \\ I822-1903}

I 822 : Born at Hartford, Conn., son of Charlotte Law Apr. 26 (Hull) and John Olmsted, prosperous merchant of Hartford.

I 826 : "At school to Mrs. Jeffry."-J. O.

A pril

I 828 : "Fredk. has been to Mrs. Jeffry's school 3 quarFeb. I 8 ters, to Mrs. Smith's one and a half, to Miss Rockwell's one. Books at Miss R's: Webster's Spelling Book, Testament, Jack Hallyard, Peter Parley's Tales, Juvenile Instructor."-J. O.

I 829 - “To Rev. Z. Whittemore, No. Guilford."-J. O. I 830 :

I 830 : "Returned home and began at Grammar School, Sep. 27 Hartford."-J. O.

I 83 I : "To Ellington High School."-J. O.

May 18

Oct. 8 "To school and board with Rev. Joab Brace, of Newington."-J. O. Remained there with visits home and trips with Father till June 30, I836, fitting for college.

"The entries marked "J. O." are from the diary of his father, Mr. John Olmsted, who kept a most careful and accurate record of the doings and movements of his family. 
I 836 : "To Rev. G. C. N. Eastman at Saybrooke."Jul. I J. O.

Sep. I “To Grammar School with John."-J. O.

Dec. I “To Mr. Perkins' school, East Hartford. Now ready to enter college."- $\mathrm{J}$. O.

I 837 : "To New York, consulted Dr. Wallace for weak eyes. Advised sea bathing. To Saybrook with Rev. Eastman again for 3 months. Advised to give up college on account of eyes. "- J. O.

Nov. 20 "To Andover, Mass., to study engineering with Prof. Barton. (Nov., I838 Mr. Barton removed to Collinsville, Conn. \& Fredk. with him. Staid till May 1840)"-J. O.

I 838 : Frederick at Andover. Summer vacation journey to White Mountains.

I 839: Father took Frederick to Washington. Home Dec. 9 Dec. 24 .

I 840 : Went to work for Benkard and Hutton, French Aug. I 8 dry goods importers, New York City. Left their employ March, I842.

I 842 : Attended lectures at Yale.

I 843: Sailed before the mast for Canton in the bark Apr. 23 "Ronaldson." Vessel back in New York Apr. I5, I844.

I 844: Spent some months at his Uncle Brooks' farm in Cheshire (Conn.) learning farming. 


\section{Biographical Notes}

I 845 : Spent summer on Mr. Joseph Welton's farm at Waterbury and winter at New Haven attending lectures.

I 846 : Went to the farm of Mr. George Geddes, "FairA p ri 1 mount," near Syracuse, N. Y., to study farming. Home in October.

I 847 : About to begin independent farming at Sachem's $\mathrm{J}$ a n' y Head, Guilford, Conn., on a small farm purchased for him by his Father.

J u n e An "honorary member" of the Class of 1847 at Yale.

I 848: Father bought for Frederick the Ackerly farm, Jan. I South Side, Staten Island, where he soon after established himself, continuing to operate it until I854.

Oct. 20 Frederick writes "full of enthusiasm on tree planting and nurseries."

I 849: Farming and beginning a nursery business.

I 850 : Sailed from New York on the "Henry Clay" with Apr. 30 his brother and Charles Brace. Returned by "City of Glasgow" with brother Oct. 24. "Expenses of journey about $\$ 300$ each. 2 weeks in Germany, 2 weeks in Belgium \& France, I week in Ireland, 3 weeks in Scotland, remainder in England."-J. O.

I 850: Corresponding Secretary of the Richmond County Agricultural Society. 
I $85 \mathrm{I}$ : Farming and writing. Visited A. J. Downing at Newburgh.

I 852: Published Walks and Talks of an American Farmer Feb. 18 in England. (G. P. Putnam \& Co., New York.)

Dec. I I Started on Southern tour.

I 853 : Letters to the New York Times began, giving his Feb. I6 impressions of the "Seaboard Slave States." (Published as a book of that title, 1856.)

Nov. Io "Fredk. and John started on their journey to Mexico and California."-J. O. (Frederick again as correspondent for the Times. Letters edited with the help of his brother and published as a book $A$ Journey in Texas, I857.)

I 854: Frederick considered settling in Texas, but returned, traveling on horseback from New Orleans to Richmond. Home summer of 1854 . (Trip home published as $A$ Journey in the Back Country, I860.)

I $855^{-}$With George William Curtis, went into partner-

I 856 : ship with Dix and Edwards in publishing business. Edited Putnam's Magazine. Publishing business failed, leaving Olmsted and Curtis liable for considerable amount of bad debts.

I 85 6: Sailed with sister Mary in "Arabia" for Europe, Feb. I3 mainly on publishing business. Spent greater part of time in London, but travelled also on continent in Italy and Germany. Mar. I2, proceeding from London to Paris with American Envoy's dispatches. 


\section{Biographical Notes}

I 8 5 7: In New York trying to wind up Dix and Edwards

Feb. Io publishing business. "Trial balance still not ready."

Sep. II Appointed Superintendent of the Central Park in New York.

I 857- At request of Calvert Vaux, collaborated with

I 858 : him in the preparation of a design for the Central Park to submit in the recently opened competition.

I 85 8: Olmsted and Vaux awarded first prize for their Apr. 28 plan submitted under the title "Greensward."

May 17 Frederick Law Olmsted appointed Architect in Chief of the Central Park.

I 8 59: Scope of the work extended by enlargement of Apr. 2 Park area to Iroth Street, by act of Legislature.

Jun. I3 Married in Bogardus House, Central Park (by Mayor Tiemann) Mary Cleveland (Perkins) Olmsted, widow of his brother John Hull Olmsted, thus becoming step-father to her children: John Charles, Charlotte, and Owen. Moved later in the summer to the old convent building at Mt. St. Vincent in the Park.

Sep. 28 Sailed for Liverpool on the "Persia," having been granted leave of absence and a letter of credit for $£$ Ioo by the Park Commissioners "to procure in Europe material and information of advantage to Central Park."

Dec. 5 Sailed from Queenstown on the "America," arriving home Dec. 18. 
I 860 : The management of Central Park investigated by the State Legislature. (Vindicated.)

Furnished to Appleton's New American Cyclopedia by request first article on Parks, in any American encyclopedia. (Volume published I86I.) See post p. I25.

Mar. 29 At Hartford with Mr. Vaux to look at the grounds of the Hartford Retreat for the Insane, for which advice and plan subsequently given.

I 860 : Olmsted and Vaux appointed "Landscape ArchiA p ri 1 tects and designers to the Commissioners North of I55th Street."

Jun. I4 A son, John Theodore Olmsted, born. Died in infancy.

Aug. 6 Thrown from carriage and thigh broken. Park work directed from bed and later from litter.

I $86 \mathrm{I}:$ Journeys and Explorations in the Cotton Kingdom in 2 volumes published in London, a compilation of the three Southern journeys already published in America in 1856, 1857, and 1860, and widely circulated as accurate information on the state of the South.

J a n' y Resignation presented to Park Commissioners (on account of political interference) and withdrawn, "all carefully kept mum so as not to embarrass the proceedings at Albany."

Apr. 17 "My resignation, and all that, is before a Committee this week." Withdrawn. 


\section{Biographical Notes}

$\mathrm{J} u \mathrm{n}$ e Leave of absence granted to go to Washington as Secretary of the United States Sanitary Commission, which he helped to organize, and of which he was (under the Presidency of Dr. Bellows) chief executive officer until 1863. Connection with Central Park still retained.

Oct. 28 Daughter, Marion Olmsted, born at Mt. St. Vincent.

I 862 : Considering possibility of securing post of U. S.

A p r i 1 Commissioner of Agriculture and Statistics (bureau proposed) as alternative to landscape gardening business.-F. L. O. letter to J. O.

O c t'r In New York to work on the Park, "object and only justification for being away from Washington."

Offered office of Street Commissioner by the Mayor of New York. Accepted "on condition that I am not to be trammelled in appointments, etc." Not consummated.

Dec. I5 Frederick met his father in New York. "Fredk's Washington address, 185 South B St., corner of W. 9th, back of Smithsonian. Office San. Com., Adams House, 244 F St."-J. O.

I 862 - Joined with Dr. Bellows, Wolcott Gibbs, and I 863 : others in the formation of the Union League Club, to perpetuate the ideals of the United States Sanitary Commission. 
I 863 : Trip to Cleveland, Cincinnati, St. Louis, Chicago, Spring etc., on business for Sanitary Commission. "Obvious want of a pleasure-ground" in Chicago noted.

May. I4 Olmsted \& Vaux resign as Landscape Architects of Central Park. Resolution of confidence passed.

Summer Obliged to withdraw from Sanitary Commission, owing to overwork.

Interested with Charles Eliot Norton and others in a project for founding a weekly review. Later, during his absence in California this project developed into the Nation.

Aug. Io Offered Superintendency of the Mariposa Mining estates in California. Accepted.

Sep. I4 Sailed without family in the "Champion" for California. Arrived at San Francisco Oct. II.

L a t e Personal property and professional library burned F a 11 while in storage at Staten Island Farm.

I 864 : Joined by family at the Mariposa Estates, Bear Early Valley.

Spring

Honorary A.M. from Harvard University, on account of work for United States Sanitary Commission.

Summer Olmsted family in Yosemite camping. Mr. Olmsted made trip Eastward through the High Sierras accompanied by John Charles Olmsted and Professor Brewer of the State Geological Survey. 


\section{Biographical Notes}

Sep. 27 Appointed Commissioner of Yosemite and Mariposa Big Tree Grove by Governor Low of California under act of Congress granting same as State Reservation. Made President of the Commission.

$\mathrm{Oct}$ ' $\mathrm{r}$ "Engaged in plans for laying out a cemetery at Oakland-and have been consulted as to a park there." (Report on Mountain View Cemetery published I865.)

Manager's General Report of the Mariposa Estates published in New York.

I 865 : Appointed on Committee for California State J a n' y Agricultural Fair.

Considers undertaking a newspaper in San Francisco "instead of going with Vaux on the Brooklyn Park."

Mar. I2 Writes to C. Vaux: "I am getting on with my cemetery-I have made preliminary reconnoissance for large piece of ground held by College of California which I propose to lay out upon the Llewellyn plan-I have given plans for improvement of a country seat."

$\mathrm{J}$ u 1 y Offers from Godkin and Norton for work on Nation and Committee of Loyal Publication Society if he will return to New York.

Jul. I9 Olmsted \& Vaux reappointed Landscape Architects to the Board of Commissioners of Central Park.

Jul. 24 "I have undertaken to lay out a village and grounds for the College of California which will occupy what time I have to spare for a month or two."-F. L. O. to J. O. 
Jul. 26 Notified of election as General Secretary of American Freedmen's Union. Refused.

Aug. 3I Proposes to accept Central Park appointment of which he has just "last night received word from Vaux" (telegraph out of order) and to resign from managership of Mariposa Estates.

S e p' r Advising on park for San Francisco.

Olmsted \& Vaux appointed to design the Brooklyn Park.

Sep. 28 Writes to C. Vaux: "I shall bring work enough to keep Miller busy for fully a month after arrival, I think. I only work out the park plans crudely here, so as to have your help on it. The profit of it I intend to share with you-also to put O. \& V. to the engraved cemetery plan if you approve. This latter also to be finished in New York."

Nov. I7 Officially selected to report to the Board of Supervisors a plan for a public park for San Francisco.

Nov. 22 Arrived with family in New York from California.

I 866: Report upon a Projected Improvement of the Estate of the College of California at Berkeley, Olmsted, Vaux \& Co., printed.

Report on Columbia Institute for the Deaf and Dumb, Olmsted, Vaux \& Co., printed, Washington, D. C.

Pamphlet: A Few Things to be thought of before proceeding to plan buildings for the National Agricultural College, printed. 


\section{Biographical Notes}

Spring Olmsted family residing at Amos Street, Clifton, near Vanderbilt's Landing, Staten Island, for Mr. Olmsted's convenience in ferrying across to Brooklyn for the Park work.

Mar. 3I Report on Public Pleasure Grounds for San Francisco submitted. (Afterwards printed.)

May 29 Olmsted, Vaux \& Co. reappointed Landscape Architects to the Board of Commissioners of Prospect Park, Brooklyn. Preliminary report of the Landscape Archi: ects was published 1866.

I 867 : Park work for New Britain, Conn.

\section{Honorary A.M. Amherst College.}

$\mathrm{J} \mathfrak{u} \mathrm{n}$ e Advice to Charles Eliot Norton on subdivision into lots and street connections of property near Harvard University. (Advice also in I868 and I 869 and later). At this time a strong friendship was formed between the Norton and Olmsted families, and Mr. Olmsted's visits to the Nortons were among the few personal visits he made.

Oct. 4 Visit to Newark, N. J., to give advice on park, followed by report. (Later printed.)

I 868: Preliminary report upon the proposed suburban village at Riverside near Chicago, Olmsted, Vaux \& Co., printed.

Reports for Brooklyn Park Commission on Washington Park, Parade Grounds, and Street Plans, printed. 
Report on proposed city park for Albany, O. V. \& Co., printed.

Feb. 8 Plan to C. E. Norton, Harvard University, for connecting walks through University grounds, vicinity Oxford Street and Norton property.

A u g' $t$ To see Barry and "learn what had become of the Rochester Park project." Also with Calvert Vaux visited Vassar College to give advice as to plan.

Aug. I4 "I have a business invitation today from Buffalo and shall splice it into the Chicago expedition in some way." Aug. 25, addressed public meeting in Buffalo in regard to Park project.

Aug. 29 Mentions jobs in letter to C. Vaux: Buffalo, Brooklyn, Chicago-Riverside.

I 869: Brooklyn park work very absorbing. (H. W. S. Cleveland employed by Mr. Olmsted on the Brooklyn work at this time.) Riverside going on. Preliminary report for Buffalo park printed.

(About) Conversation at Cataract House with Mr. William $S$ e p' $r$ Dorsheimer and others regarding the preservation of Niagara Falls.

I 870 : Reports: on park for New Britain; to Mr. J. S. Blatchford (Boston) on Needham Hundreds (suitability for residential land subdivision); to Maine Agricultural College (printed); and on park site for Hartford (probably I870).

Address before American Social Science Association at Lowell Institute, Boston: Public Parks and the Enlargement of towns (printed). 


\section{Biographical Notes}

Mar. 5 Appointed on the Commission for the Improvement of Staten Island, with H. H. Richardson and others.

Apr. 5 Advice to Amherst College.

Apr. 7 Olmsted, Vaux \& Co. agreement with Chicago South Park Commission.

J u n e O. V. \& Co. Report to the Committee on Park Improvement, Fall River.

Jun. 2 O. V. \& Co. letter refers to "Recent changes of administration in Central Park, and change of organization now occurring with pending legal proceedings threatening from day to day a suspension of work on the Brooklyn Parks under our superiritendence."

Jul. 22 Advice to C. K. Hamilton in regard to proposed resort or "exposition" on Staten Island.

Jul. 24 Son, Frederick Law Olmsted, Jr., born.

Aug. 2 Letter of advice to General Meigs in regard to planting of National Cemeteries.

Nov. 30 Olmsted and Vaux resigned from their Central Park duties after their advice had been disregarded and politics rendered their situation impossible.

I 87 I : Reports for Chicago South Park and Staten Island improvement printed.

Mar. I I Olmsted, Vaux \& Co., asked to prepare a plan for park in Philadelphia and preliminary sketch submitted. 
$\mathrm{J}$ u 1 y "My age is 50 years, residence New York City, occupation Landscape Architect."-F. L. O. in deposition.

At work on Tarrytown Heights subdivision.

S e p ' r Shared house in 45 th St. with friends, and spent there winter of $187 \mathrm{I}-\mathrm{I} 872$.

$\mathrm{O} c t$ ' $r$ Advice on subdivision at Irvington, N. Y. for Cyrus W. Field. (Olmsted, Vaux \& Co. Memorandum of suggestions printed.)

Nov. 23 Olmsted and Vaux reappointed Landscape Architects of New York Department of Public Parks.

I 872 : Report on new suburban district of Tarrytown F e b'y Heights, Olmsted, Vaux \& Co. (printed).

M a y Report on sites for Trinity College, Hartford.

May 29 Appointed a Commissioner of the New York Department of Public Parks, and elected President and Treasurer of the Board. (Calvert Vaux appointed Landscape Architect.) Resigned and reappointed Landscape Architect, Oct. 24, C. Vaux becoming Consulting Landscape Architect.

Oct. I8 Partnership between Olmsted and Vaux dissolved for reasons of mutual convenience.

L a $t$ e Moved to house at 209 West 46 th Street, perma-

$F$ a 11 nent residence and office until I 883 (although most of time subsequent to I 880 actually spent in Boston). 


\section{Biographical Notes}

Dec. 13 Report to Massachusetts General Hospital on sites for its "Retreat for the Insane." (McLean Asylum.)

Dec' $r$ Memorandum from account sheet "Vaux in a/c with O. \& V." Brooklyn; Fall River Park Dept.; Central Park; Chicago expenses; Philadelphia expenses; Poughkeepsie expenses; Providence Park; W. B. Ogden; Trinity Bridge; Tillinghast; F. E. Church (place on Hudson); Chase; Barr; McCormick. Undetermined a/c: Phila. Park; Tarrytown extra work; Finance Dept.; Mr. Gillette, Kaatskill.

I 873 : Year marked by very active work on the Central Park and the preparation of a large number of special reports, including reorganization of the Keepers force, Statistical Report of the Landscape Architect with historical survey of Central Park, etc.

Preliminary visit to Mount Royal, Montreal. This was made the occasion of a pleasure trip in which Mrs. Olmsted and the H. H. Richardsons participated.

Jun. 17 Attended Rhododendron Show of Massachusetts Horticultural Society on Boston Common as representative of the N. Y. Dept. of Public Parks.

Aug. I7 Reports on examination of land in Waverly for McLean Asylum,-3d report on subject.

Sep. 17 Presented resignation as Landscape Architect of the N. Y. Dept. of Public Parks. Consented "to resume service under the Commission upon a modified arrangement, vindicating my professional standing and securing me against another similar experience." 
I 874 : Coöperated with Mr. Weidenmann on Hyde estate. Checks deposited for services Oakwood Cemetery (Syracuse), Amherst (Mass.) Common, Yale College, and for grounds of Mr. Lord, Morristown, N. J.

On salary from Buffalo Park Commission and United States Capitol.

Several special reports on Central Park printed.

J a n'y Report submitted to Senator Morrill on Public Grounds at Washington, including Capitol grounds and area to Lafayette Square. Mr. Olmsted's Capitol work was facilitated by his coöperation and friendship with Edward Clark, who held the office of Architect of the Capitol.

A p r i 1 Design for United States Hotel grounds, Saratoga Springs.

May I Entered into working arrangement with $\mathrm{Mr}$. Jacob Weidenmann, landscape architect, then of New York, to use his office facilities and secure occasional coöperation. Draft of announcement reads: "Mr. Olmsted and $\mathrm{Mr}$. Weidenmann can at all times be commanded for any business of their common profession."

May I4 Planting plan and report for Jeffersonville (Ind.) U. S. Army Depot.

Jun. 27 Report to Hartford Insane Retreat on west portion of grounds. 


\section{Biographical Notes}

Nov'r Engaged for advice on the development of Mount Royal Park, Montreal, and furnished written instructions during progress of construction (18741876).

D e c'r Deposited check from Johns Hopkins University for plan.

I 875: Engaged in giving advice for the laying out of a "summer village" at Chatauqua Point.

Plan for the new stairways and terraces west of the U.S. Capitol favorably reported by the Committees of Public Buildings and Grounds and adopted by Congress.

Reports for Buffalo and New York City parks (Riverside Park with Vaux) printed. Revised article on Parks in Appleton's Cyclopedia published.

M a y Gives advice as to lay-out of grounds and placing of buildings, Trinity College, Hartford, to replace plans previously given, but mislaid.

May 6 Requested by the Q. M. General of the War Dept. to furnish plans for the "improvement of its grounds in a tasteful manner" of the Schuylkill Arsenal, Philadelphia.

$\mathrm{J}$ u n e Plans for McLean Asylum lay-out requested, on site in Waverly recommended.

After graduation from Sheffield Scientific School at Yale, John Charles Olmsted became an apprentice with Frederick Law Olmsted. 
Jul. 3I Visit, consultation and advice to Park Commission, Providence, R. I.

Oct'r- In correspondence with Boston Park CommisNov'r sioners about the Boston Park system.

Nov. 5 "The Landscape Architect is hereby requested to prepare a plan for laying out the Annexed district of the 23d and 24th Wards," City of New York.

I 876 : Prepared for Centennial Exposition, Philadelphia, a map of Buffalo showing "late additions to the plan."

Mar. 3 Report of Advisory Board on plans of the new Capitol at Albany (Olmsted, Eidlitz, and Richardson). Later printed. The friendship of the three collaborators in this Albany work became life-long.

March - Reports for Johns Hopkins University on "Clifton J u n e Estate" site.

Apr. 8 Letter to Boston Park Commission on proposed park sites: Charles River embankment, Back Bay, Jamaica Pond, West Roxbury.

May 3I Accepted unpaid office under the New York State Survey, from which he resigned in August because he was advised that it was doubtful if he could legally hold office under both New York City' and State. Political enemies caused his salary as Landscape Architect to the N. Y. Dept. of Public Parks to be withheld, for which he entered suit. Suit won 1877 on ground that the Landscape Architect of the City of New York was not an officer. 


\section{Biographical Notes}

Aug. 4 Reinstated by resolution of the Commissioners of the N. Y. Dept. of Public Parks, a resolution to discontinue his services failing to pass.

Nov. 13 Deposited check from Buffalo State Asylum for grounds.

Nov. I5 Submitted Preliminary Report of the Landscape Architect and the Civil and Topographical Engineer (Croes) upon the laying out of the $23 \mathrm{~d}$ and 24th Wards (New York City). Report "introductory to a series of plans for laying out the new wards of the city. The first of these can, if desired, be laid before the Board at its next meeting, a second and third are in preparation and the whole series is in progress of study." All later printed, including report on local steam transit routes (I877).

D e c'r Advice to Baltimore on Washington Monument grounds.

I 877 : Construction work on the United States Capitol proceeding according to his plans.

J u 1 y Mentions Baltimore, Washington, and Montreal as going on.

Jul. I5 "I am warmly engaged in the fight upon the (N. Y. State) Capitol just now, having been most of the time the last two weeks in Albany."

Dec. I2 Board of Commissioners of the N. Y. Dept. of Public Parks orders Mr. Olmsted's salary, withheld by Comptroller on account of charges against him, to be paid. 
Dec. 26 Board grants him leave of absence for three months without pay on account of ill health.

I 878 : Removed by the Board as Superintendent of the Jan. 5 Bureau of Design of the N. Y. Dept. of Public Parks, on alleged grounds of economy, it being stated in the resolution of removal that his services might later be availed of as necessary. The conclusion of a long and harassing political persecution.

Jan. 8 Sailed for Europe for four months, where he travelled about accompanied by J. C. Olmsted. Places noted as being visited: Birkenhead Park, London Parks, Bruges Park, The Hague, Amsterdam, Frankfort, Munich, Venice, Florence, Pisa, Genoa, Milan, Como, Maggiore, Turin, Macon, Dijon.

M a y Commissioners of the Connecticut State Capitol authorized to consult Mr. Olmsted about laying out Capitol grounds at Hartford. (Reports in July and August.)

J u 1 y Writes Édouard André in regard to his professional work, mentioning as especially important the Arboretum at Boston and the Capitol at Washington.

Summer Spent with E. L. Godkin in Cambridge in order to work out plans for Arboretum with Professors Gray and Sargent.

Dec'r Memorial for preservation of Niagara Falls in course of receiving signatures. Charles Eliot Norton writes to Mr. Olmsted Dec. 23, "Carlyle signs." 


\section{Biographical Notes}

Articles of agreement between Mr. Olmsted and the Park Department of Boston in regard to "Back Bay Park."

I 879 : Writes to É. André, "I am doing but little pro-

Jun. 6 fessionally, my most important active work ieing the Capitol Grounds at Washington." Work also on Boston Parks (Back Bay), Arboretum, and campaign for protection of Niagara Falls.

Summer Lived partly in Brookline and partly with E. L. Godkin in Cambridge.

Jul. 30 Report on development of Rockaway Point as amusement resort, following visits earlier in July to Rockaway and Coney Island.

A u g' t Advice to J. Letchwarth, Auburn, N. Y., as to his country place.

S e p'r Vacation trip to New Brunswick and Quebec.

Oct. Io Writes to Charles Eliot Norton that he has met four of the N. Y. State Niagara Commissioners and the Premier and members of the Council of Ontario, and his general scheme has been approved. James T. Gardiner, Director of the State Survey, had been instructed by joint resolution to see what measures were expedient for the preservation of Niagara and to prepare a project and associate with him Mr. Olmsted. Report published I880.

N ov' $r$ Deposited check for plan of "Belleview" suburb of Newark, N. J. 
Nov. 3 Visit to Boston, chargeable each one third to Arboretum, Schlesinger (estate, Brookline), and Boston Park Department.

Nov. 19 Visit to Utica and Albany, chargeable to State -2I Survey.

Nov. 22 Visit to Washington, chargeable to U. S. Capitol grounds.

I 880 : "My business lies now more in Boston than New York." Main work still Boston Parks, Capitol at Washington, and Niagara.

Read at meeting of American Social Science Association, at Saratoga, paper: A Consideration of the Justifying Value of a Public Park. (Published I881.)

Advice as to trees in Jerome Park, Sheepshead Bay Race Course.

Jul. 14 Asked by C. A. Dana of the New York Sun to write a series of "a dozen or 20 or 30 " articles on the best private parks, grounds, or estates, in all parts of the country. Declined.

I 88 I : Numerous visits to North Easton on Memorial work.

Report for Mount Royal Park printed.

Work for Boston Parks proceeding, including suggestions for The Improvement of Muddy River. (Printed.)

J a n'y Professional letterhead:

F. L. Olmsted 209 West 46th St.

J. C. Olmsted New York 


\section{Biographical Notes}

Apr. 2I Deposited check from James T. Gardiner for report on Niagara to State Survey Commission.

Jul. I Bill to Montauk Association for advice as to disposition of cottages in summer colony at Montauk.

Sep. 27 Advice on the forest treatment of Phillips estate at Beverly, Mass.

I 88 I - Residence mainly in Brookline.

I 882 :

Winter

I 882 : Reports printed relating to U. S. Capitol at Washington, Albany State Capitol, and Belle Isle Park, Detroit.

F e b'y Published: Spoils of the Park with a few leaves from the deep laden note book of "a wholly unpractical man," a reminiscent account of political interference in the management of Central Park. Just after this, he wrote to a friend; "You can have no idea what a drag life had been to me for three years or more. I did not appreciate it myself until I began last summer to get better. The turning point appears to have been an abandonment of New York. ... I I have done much hard and steady work. The pamphlet of which you speak was mostly written after midnight and did not prevent me from getting regularly five or six hours refreshing sleep. I enjoy this suburban country beyond expression and in fact, the older I grow, find my capacity for enjoyment increasing. We have had great trials and agitations in the last year but the result of the whole has been with all tranquillizing. I am to turn sixty with two grandsons." 
Nov. 9 Letter to J. C. Olmsted mentions jobs going on: Washington Capitol, Detroit Park, Boston Parks (Back Bay and Commonwealth Avenue), Providence (land subdivision), North Easton (memorial -Ames), Newport (Easton's Beach and private estates), Albany State Capitol, Buffalo and Bridgeport Parks, Niagara Reservation. Jobs in $\mathbf{1} 882$ also on Boston \& Albany R. R. station at Auburndale (Mass.), Aspinwall Land Company subdivision, Summit (N. J.) Improvement Association, Quincy (Mass.) Library, Weld estate at Dedham, H. H. Hunnewell estate at Wellesley, and for many other private clients.

I 882 - In Brookline, at Taylor house on Dudley Street.

I 883 :

Winter

I 883 : Bought house at 99 Warren Street, Brookline, which became permanent home and office.

Charles Eliot an apprentice with Mr. Olmsted (until I885).

Work going on for Boston Parks and Arboretum, Detroit Park, U. S. Capitol, Goddard land subdivision at Providence, Cushing's Island in Portland Harbor, Boston and Albany R. R. (stations at Beacon Street, Allston, Brighton, Faneuil, Newton, Newtonville, West Newton, Riverside, Brookline, Reservoir, Chestnut Hill, Newton Center and Palmer), Massachusetts General Hospital (McLean) Insane Asylum at Waverly, Lawrenceville School, Amherst College, and Madison (now Colgate) University, and many private clients. 


\section{Biographical Notes}

Active assistance to successful conclusion of campaign for the preservation of Niagara Falls, in which Mr. Olmsted was interested, with Messrs. Potter, Dorsheimer, Norton, and others, since I869.

I 88 4: John Charles Olmsted taken into full partnership. Firm name: F. L. \& J. C. Olmsted.

Participation in campaign for preservation of Adirondack region.

Work recorded for Amherst College, University of Vermont, Groton School, Memorial Park at New London, Boston and Albany Railroad, Town of Brookline (Aspinwall Avenue region), Brookline Country Club (drainage), Narragansett Casino Company. Among others, advice given for estates at Lenox, Stockbridge, Beverly, Waltham, Mass. Land subdivisions planned at Chestnut Hill (Mass.), Newport, Providence, Yonkers, and five or six other places.

J a n'y "Went with Richardson the architect to Malden and determined the site of the proposed memorial Library."

Mar. I I "I expect to leave Friday evening at latest with my preliminary plan for Belle Isle."

May 24 Mentions in letter to J. C. Olmsted jobs on Trenton and Boston parks, Capitol at Washington, Lawrenceville School, Chestnut Hill, Cypress Street, and Brookline stations, and visit with McKim to Stillman place above Sing Sing. 
Sep. 23 Wrote to Boston Park Commissioners on lay-out of a park at West Roxbury (later Franklin Park).

D e c ' r Asked to be one of two experts to conduct the first Civil Service examination in landscape gardening given by New York Department of Public Parks for position "superintendent of gardening."

I 885 : Work for City of Boston (Back Bay, Wood Island, West Roxbury Parks, and Massachusetts Avenue), Town of Brookline (new street lay-out Harvard Street-Aspinwall Avenue region), Amherst and Smith Colleges, Groton and Lawrenceville Schools, Boston and Albany Railroad (Palmer and Wellesley Hills), McLean Asylum, Cairn Memorial at North Easton, Billings Library at Burlington, and fifteen or twenty private clients.

I 886 : List of clients during the year includes: U. S. Capitol, Niagara, Stanford University, a Society at Amherst, Lawrenceville School, Groton School, McLean Asylum, Newport Hospital (land subdivision), Rotch Memorial Church, B. \& A. Palmer Station, Brookline Country Club, Boston and Buffalo Parks, Bridgeport Park, New York Riverside Park, a half dozen land subdivisions in Brookline (including Beacon Street region) and Buffalo, Vanderbilt Tomb, Andrew Carnegie, and about thirty other private clients.

Report: Notes on the Plan of Franklin Park and related matters, printed.

Mar. I6 Had just been to Lenox where he had "been advising a Vanderbilt colony." 


\section{Biographical Notes}

A u g ' $t$ Started for California, in connection with proposed university for Governor Stanford. En route, visited Minneapolis parks and saw H. W. S. Cleveland there.

Sep. 29 "Site settled at last" for new University at Palo Alto.

Sep. 30 In San Francisco and "hope to see the park" (twenty years after his original design of 1866). Visit followed by brief report (printed).

Oct. 17 Reached Boston from California.

I 887 : Work going on especially for Boston and Buffalo Parks, two land subdivisions in Brookline and one or two in Buffalo, and Arboretum for Dr. Webb at Shelburne, Vt. Studies being made for a report on National Zoo at Washington.

General plan for the improvement of the Niagara Reservation, by F. L. Olmsted and Calvert Vaux, printed by the State of New York.

Interested by Professor Sargent in the founding of Garden and Forest, a journal to promote the landscape art. During the illness of the directing editor Professor Sargent, Mr. Olmsted undertook much work in connection with the magazine.

Jan. 26 From Salt Lake City, having visited Black Rock, Garfield, and Lake Point, writes to C. F. Adams, President of Union Pacific Railroad in regard to proposed hotel development at Garfield. 
F e b'y Sounded in regard to advice to Canadian Commissioner of Niagara. (Letter of advice sent in August.)

Apr. 20 Appointed at a meeting of Board, Department of Public Parks of New York City, Landscape Architect Advisory to the Board. Subsequently visits made and advice given mainly in regard to Morningside and Riverside Parks. Connection suspended by Mr. Olmsted, July I887. General Plan for Morningside Park, with Calvert Vaux, printed. Received check July 5, for "consultation as to Riverside etc. last year."

Oct'r Trip to California in connection with the development of Leland Stanford Jr. University.

D e c'r Report in letter to chairman of the Park Commission, St. Catherine's, Ontario, for Montebello Park.

I 888 : Major public work, for parks of Buffalo and Rochester, N. Y.; Leland Stanford Jr. University; park system report (with J. C. Olmsted) for Pawtucket, R. I. Advice or plans given for Redstone Mining town, and land subdivisions at Brookline (Corey Hill), Chestnut Hill, Readville, and Swampscott, Mass., Newport, R.I., Buffalo, and several other places, and for proposed hotel at Lake Sunapee; also for a large number of private estates and for Groton and Lawrenceville Schools. Requests for designing two cemeteries refused.

A ug't Engaged in preliminary discussion of proposed Biltmore estate for Mr. George W. Vanderbilt, at Asheville, N. C. Survey begun in October. 


\section{Biographical Notes}

I 889: Henry Sargent Codman taken into partnership. Firm name: F. L. Olmsted \& Co.

Advice to New York Department of Parks against Speeding Track in Central Park.

Advice on park matters given to Arlington, Newton, and Plymouth, Mass., and Providence, R. I., besides Boston and Brookline (Muddy River improvement). Work for Leland Stanford, Groton School, Leake and Watts Orphan House, memorial chapel at Falmouth, and B. \& A. Wellesley station; Perry Park (Prospectus I890) and Lake Wauconda subdivisions near Denver, "World's End" development on Boston Harbor, numerous other subdivisions, and a large number of private estates, including "Biltmore".

Report on Central Park published: Observations on the Treatment of Public Plantations, prepared with J. B. Harrison at instance of West Side Improvement Association, New York City.

Feb. 25 Read paper at Brookline Club: Our Roads and What They are leading us to.

A p r i 1 Advice to the Governor of Alabama in regard to State Capitol grounds at Montgomery.

$\mathrm{J} \mathfrak{u} \mathrm{n}$ e "Getting figures for marble fountain on Capitol terrace" at Washington. Also visited Biltmore.

Aug. 6 Addressed as Consulting Landscape Architect, New York Department of Public Parks.

S e p ' $r$ Asked to give his views on sites in New York City for World's Columbian Fair, and aided movement against proposed location in Central Park. 
Nov'r Advice to Lynn (Mass.) Park Commissioners in regard to Lynn Woods. (Report on this subject printed $\mathbf{1 8 9 2 . )}$

D e c'r Advice to Newburgh on Downing Park. Calvert Vaux associated on report.

Earl of Meath suggested that Mr. Olmsted go to London to advise Meath's commission on the beautifying of the old burial grounds of London.

I 890 : "My office is much better equipped and has more momentum than ever before." "I am at this time (with my partners) the landscape architect of twenty works of considerable importance, that is to say, I do not include in that ordinary private grounds. Nine of these twenty are large public parks of cities; two, government works; three, works of commercial corporations; one, of a benevolent corporation, and six, private undertakings of such character as to make them matters of public interest, operations on them being systematically reported in the newspapers." (The works of commercial corporations alluded to were land subdivisions, and the cities to which advice on park matters had been rendered particularly at this time included Boston,-Marine and Wood Island Park reports printed I890,-Rochester, New York City, Wilmington, and Hartford. The most important private work was Biltmore, the new Vanderbilt estate at Asheville, N. C., the remainder mentioned being other Vanderbilt, Rockefeller and Twombly estates.)

Collection of United States Sanitary Commission Papers arranged by Mr. Olmsted, and presented 


\section{Biographical Notes}

by him with an introductory statement (printed), to the Loyal Legion of Boston.

Issued leaflet in regard to the Yosemite: Governmental Preservation of Natural Scenery.

$\mathrm{J}$ u $\mathrm{n}$ e Report: Project of Operations for the Improvement of the Forest of Biltmore, sent Mr. Vanderbilt.

$\mathrm{J}$ u 1 y Consulted by Superintendent of West Point as to course to be pursued in future development of West Point.

A ug 't In Chicago reporting on a site for the World's Fair.

D e c'r Advice to Marblehead on proposed shore road.

I 89 I : Deposited check for services on National Zoological Jan. I6 Park.

Jan. 20 Writes to Frederick Kingsbury: "Our Southern circuit includes, or has recently included, Richmond, Montgomery, Knoxville, Nashville and Louisville [parks]. In the far West we have works in progress, two in Colorado and one in California. Altogether I have to do a great deal of long journeying . . . but personal activity on the ground . . . is the part of the work I can least turn over to my partners." As to the Biltmore estate, he says: "I have been giving it practical form and have each division of the scheme in operation." The other Vanderbilt commissions are mentioned, then:- "Our business is constantly increasing and in such a way that it is impossible to get the additional assistants for it, being of a class of which 
there are but few accomplished in the world; so we are always personally under an agitating pressure and cloud of anxiety. The most serious point just now is Chicago" (World's Fair). Chicago and Biltmore claimed the major part of his time. $\mathrm{He}$ also gave personal attention to the site of the Soldiers' Memorial Arch at Concord, N. H., to Presque Isle at Marquette, Mich., and to the Rochester Parks.

March Invited by the Brooklyn Park Commissioners to examine the plantations in Prospect Park.

O c t'r Advice to Elmwood Cemetery, Detroit, suggesting "certain general principles as to future management."

Nov'r Letter to Mr. Newlands on subdividing property in Washington, D. C., and streets in the new Connecticut Avenue district.

I 892 : Consulted by the United States Government on the development of the reservation at Hot Springs, Ark.

March Trip from Biltmore to Knoxville to Louisville to Chicago to Rochester to Boston.

Apr. 2 Sailed for Europe for rest, accompanied by Philip Codman, F. L. Olmsted, Jr., and Marion Olmsted. Illness while abroad prevented his doing much travelling for professional study himself, although he moved somewhat about England and France. He directed the studies of his pupils Philip Codman and F. L., Jr., with constant interest, and he was able to make a study of pleasure boating on the 


\section{Biographical Notes}

Thames as a basis for the scheme of water activities on the Lagoons of the World's Fair, subsequently carried out.

Jun. I6 In a letter to his office from England, he asks after the following jobs: World's Fair, Louisville, Marquette, Whitelaw Reid, Twombly, and Newport.

Jul. 30 Writes his partner, Harry Codman: "I assume that very soon after my return it will be desirable, extremely desirable, that I should take a very long railroad journey, Rochester, Chicago, Louisville, Kansas City (parks), Biltmore, Atlanta and various places nearer home. I did not mention Milwaukee and Marquette."

Oct. I I In Chicago on World's Fair business, having just returned from Europe. He feels the need for opening a Western office and mentions being about to leave for Kansas City.

Oct. 2I Present at the Dedication Ceremonies of the World's Fair and received one of the special medals "struck in recognition of the services of the Architects, Artists and Designers of the World's Columbian Exposition ... the first time in the history of the country that such services have been publicly recognized."-Letter of invitation from D. H. Burnham.

Nov'r At Biltmore for conference with Mr. Vanderbilt. Mentions in a letter to J. C. Olmsted that he feels "guilty of neglect of Boston work."

I 893: Report printed on the occupation of the new site for Columbia College (New York), by F. L. O. and W. R. Ware. 
Article on Mr. Olmsted by Mrs. Van Rensselaer published in the Century Magazine with Mr. Olmsted's consent and based on information which he mainly furnished.

J a n'y Sudden death of Harry Codman, on whom Mr. Olmsted had "thrown a good deal" of the World's Fair work, made it necessary for Mr. Olmsted "to jump in and shoulder the Chicago work with others for a time, and so manage them that with good luck nobody complained and I was even myself not extremely dissatisfied with the results."

F e b'y Charles Eliot taken into partnership with F. L. Olmsted \& Co. On March I 5 the firm name was changed to Olmsted, Olmsted \& Eliot.

Feb. I7 Writes to J. C. Olmsted that he considers of major importance the following jobs: Boston parks, Boston Metropolitan parks (brought in by Charles Eliot), Columbian Exposition, Biltmore estate, Bay Ridge Parkway in Brooklyn, the parks in Louisville, Kansas City, Milwaukee, Rochester, Buffalo, the two Newport places, Lenox, Monmouth County place, N. J. He adds "I wish that we could drop the three last and everything else." ... "I do think that we shall have to decide on throwing up a lot of our business. I am not to be depended on (Mr. Olmsted was then nearly seventyone years old) ... Common prudence requires that you should lay out your course not counting on me." From this time on Mr. Olmsted declined personal responsibility for all private work, counting Biltmore because of its magnitude a semipublic undertaking. 


\section{Biographical Notes}

Mar. $23 \mathrm{~A}$ guest of honor at the dinner ${ }^{\mathrm{x}}$ given to $\mathrm{D}$. $\mathrm{H}$. Burnham and other artists of the World's Columbian Exposition by fellow architects and the City of New York. During the speaking Charles Eliot Norton said: "Of all American artists, Frederick Law Olmsted, who gave the design for the layingout of the grounds of the World's Fair, stands first in the production of great works which answer the needs and give expression to the life of our immense and miscellaneous democracy." Mr. Burnham said: "Each of you knows the name and genius of him who stands first in the heart and confidence of American artists, the creator of your own parks and many other city parks. He it is who has been our best adviser and common mentor. In the highest sense he is the planner of the ExpositionFrederick Law Olmsted. No word of his has fallen to the ground among us since first he joined us some thirty months ago. An artist, he paints with lakes and wooded slopes; with lawns and banks and forest-covered hills; with mountain-sides and ocean views. He should stand where I do to-night, not for his deeds of later years alone, but for what his brain has wrought and his pen has taught for half a century."

Apr. Io Slept in Cleveland to break the journey to Chicago (has had to give up sleeping on the train) and writes to J. C. O. "you might send me also the Harvard College map. I may have a chance to study it and be prepared for discussion with Eliot."

J $\mathfrak{u}$ n e LL.D. degree from Harvard and LL.D. also from Yale. The Harvard degree was conferred by

A A full account of the dinner is given in Vol. I of D. H. Burnham, by Charles Moore, Houghton Mifflin Co., I92 I. 
President Eliot in the following words: Fredericum Law Olmsted, qui, ruris specie in urbes introducta, casas pauperum, domus feliciorum, cedificia publica exornavit, aque saluti et delectationi civium omnium consuluit.

S e p' $r$ Charles Eliot "is now in the West as my alternate for various professional consultations with Milwaukee, Louisville, Kansas City, and other corporations. John travels less than the rest of us, being in direction of the office in which there are fifteen to twenty draughtsmen and clerks, the preparation of work for whom over-fully occupies him. I have come to greatly dread traveling. . . . I suppose that as long as I live I shall be forced to make long journeys to meet Boards, Legislative Committees, etc., as, although the young men may be my superiors, they cannot testify with the weight of experience that I bring."

Oct. I8 Writes back to his office about the Hot Springs matter (on which there had been government misunderstanding) while on "a bad piece of Richmond and Danville R. R." on his way to Biltmore.

Oct. 24- At Biltmore "mainly engaged on the Arboretum." Nov. 20

Nov. 23 At Atlanta in connection with the proposed Cotton Exposition, at the instance of Mr. Joel Hurt.

Dec. 30 Formal letter to Mr. Vanderbilt about the Biltmore Arboretum, outlining general matured scheme and enclosing the announcement printed in the Lyceum in 1891 regarding the Arboretum. 


\section{Biographical Notes}

A list of the firm's public clients includes the following not mentioned by Mr. Olmsted in letters just quoted: College of N. J. (Princeton), Wilmington Park Commission, Trinity College, U. S. National Zoological Park at Washington, and Kirkwood Land Company, Atlanta.

I 894 : Reports, by Olmsted, Olmsted \& Eliot, on Cambridge parks and Charles River Embankment printed.

J a n'y In Cincinnati on park work.

Fe b'y Advising on Brooklyn Park. Last of the month in Biltmore.

March Visited Chicago South Parks and Milwaukee en route to Louisville. Wrote to J. C. O. that it is very desirable to make the firm favorably known in the South and "extend its connection."

$\mathrm{M}$ a $\mathrm{y}$ Again in Biltmore.

S e p ' r Advice to Town of Brookline "on main roads and public reservations in that part of Brookline bounded by Boylston St., Chestnut St., Goddard Ave., and Clyde St." (printed.)

Nov'r- The Olmsted family at Biltmore.

Dec'r

I 895: At Biltmore. The last of May he left with his Feb'y- family to come North, leaving his son F. L. O., $\mathrm{M}$ a $\mathrm{y} \mathrm{Jr}$., as his professional representative.

Spring Portrait painted outdoors at Biltmore by John Singer Sargent. 
$\mathrm{June-}$ In Brookline. Some fragments of manuscript on

J $\mathrm{u} 1$ y the Hartford parks about this time were probably his last professional writings except letters of advice to F. L. O., Jr., at Biltmore in regard to the Summer and Fall work there.

Aug't- At Deer Isle, Maine, the family's summer home, Oct'r resting.

S e p'r Retired from professional practice.

N ov'r Sailed for England with Mrs. Olmsted, F. L. O., Jr., and Marion Olmsted.

D e c ' r Wrote to F. L. O., Jr., in another part of England, as to plants, deer, etc. for Biltmore. Shortly after this his mind failed, after nearly forty years of active professional work.

I 903 :

Aug. 28 Died. 


\section{PART II. EARLY EXPERIENCES}

THEIR CONTRIBUTION TO HIS LATER CAREER 



\section{PART II. EARLY EXPERIENCES}

\section{THEIR CONTRIBUTION TO HIS LATER CAREER}

\section{CHAPTER I}

\section{AUTOBIOGRAPHICAL PASSAGES}

OF the early influences and experiences which contributed to Mr. Olmsted's unconscious preparation for his later professional practice, we have fortunately a considerable record. Towards the close of the seventies, when he was harried beyond measure by the New York politicians, he set down some fragmentary autobiographical notes as the first part of an intended book reviewing American social and political conditions.

In a little prefatory note, he says:

. . I I offer a small contribution of individual experience towards the history of the latter half of the first century of the American republic,- - the period in which the work of the railroad, the electric telegraph, the ocean steamship, the Darwinian hypothesis, and of Universal suffrage began; in which what is called the temperance reformation and the abolition of slavery have occurred; in which millions of people have been concentrating at New York, Philadelphia, Boston, Baltimore, Cincinnati, Chicago, St. Louis, and San Francisco, while rural neighborhoods in New England, Virginia, the Carolinas and Georgia have been rapidly losing population and still more rapidly losing various forms of wealth and worth. 


\section{$44 \quad$ Frederick Law Olmsted}

The book was never written, but he preserved such pages of manuscript as he found time to scribble off,- - often at night when the strain of his bitter fight for the right development of the Central Park left him sleepless and when he turned with relief to the recollections of a simple and harmonious social group. 


\section{Passages in the Life of an Unpractical Man}

His teachers are the people, books, animals, plants, stones and earth round about him.-Philip Gilbert Hamerton.

My father was well fitted to live only in a highly organized community in which man's stint is measured out to him according to his strength. As the world is going he was perhaps as fortunately placed in this respect as he well could be. Yet the world was driving along so fast that he lived in perplexity between his self-distrust and disposition to acquit himself fully in his proper part, and the supposed demands of Society, Religion and Commerce.

The affectations by which he aimed to hide his unreadiness were so transparent and his real qualities had so little of brilliancy that he passed with others, even with many of his friends, for a man of much less worth, ability and attainments than he was.

If one had said to my father that he was highly sensitive to beauty he would have straightened himself, coughed and bridled like a girl, in the desire to accept flattery with becoming deprecation and admission. And he would probably soon after try to justify the compliment by referring admiringly to something which he thought had the world's stamp of beauty upon it, quite possibly something which, but for the stamp, would be odious to him.

He rarely talked even in his family on matters at all out of the range of direct and material domestic interests, and in a company where lively conversation was going on, would sit silent and even answer questions unfrankly and with evident discomfort. Yet though his communion with others was 
never wordy, a decided companionship was always necessary to his comfort, and his silence was never churlish.

His sensitiveness to the beauty of nature was indeed extraordinary, judging from the degree in which his habits were affected by it; for he gave more time and thought to the pursuit of this means of enjoyment than to all other luxuries, and more than any man I have known who could not and would not talk about it or in any way make a market of it.

My mother died while I was so young that I have but a tradition of memory rather than the faintest recollection of her. While I was a small schoolboy if I was asked if I remembered her I could say "Yes; I remember playing on the grass and looking up at her while she sat sewing under a tree." I now only remember that I did so remember her, but it has always been a delight to me to see a woman sitting under a tree, sewing and minding a child.

My [step-]mother's character was simpler than my father's, but she also had a strong love of nature and her taste was more cultivated and had more of her own respect.

$\mathrm{My}$ father when a young man was fond of riding and before I could be trusted alone on a horse was in the habit of taking me sitting on a pillow before him. While still very young I rode by his side.

The happiest recollections of my early life are the walks and rides I had with my father and the drives with my father and [step-]mother in the woods and fields. Sometimes these were quite extended, and really tours in search of the picturesque. Thus before I was twelve years old I had been driven over the most charming roads of the Connecticut Valley and its confluents, through the White Hills and along most of the New England coast from the Kennebeck to the Naugatuck. We were our own servants, my father seldom fully trusting strangers in these journeys with the feeding, cleaning or harnessing of his horses. We rested long in pleasant places; and when at noon we took the nags out and 


\section{Autobiographical Passages}

fed them by the roadside, my father, brother and I would often wander far looking for a bathing place and an addition of fresh wild berries for the picnic dinner which my mother would have set out in some well-selected shady place.

I had also before I was twelve traveled much with my father and mother by stage coach, canal and steamboat, visiting West Point, Trenton Falls, Niagara, Quebec, Lake George.

I recollect less of any enjoyment I may then have had than of my impression of the enjoyment my father and mother constantly found in scenery. Yet they could have talked little of it, both being of silent habits; and I am sure that they did not analyze, compare and criticise.

These reflections rise naturally when I review the conditions of my education, for although I was much separated from my father and few men have less aptness, inclination or ability than he had to give oral instruction, I see that the unpremeditated and insensible influence which came to me from him was probably the strongest element in my training. I see also that my father may have unwittingly disclosed to me more of his nature than to any one else. One of two or three incidents that remain in my mind will show what I mean. On a Sunday evening we were crossing the meadows alone. I was tired and he had taken me in his arms. I soon noticed that he was inattentive to my prattle and looking in his face saw in it something unusual. Following the direction of his eyes, I said: "Oh! there's a star." Then he said something of Infinite Love with a tone and manner which really moved me, chick that I was, so much that it has ever since remained in my heart.

Brought up in a superstitious faith in preaching and didactic instruction, and knowing how little he could by deliberate purpose do for me in that way, my father's affection and desire to "do right by the boy" made him always eager to devolve as much as practicable of the responsibility of my education upon ministers. 
I was placed successively in charge of six ministers. That this was not a choice of schoolmasters appears from the fact that while living with three of them I was, with my father's knowledge, sent out by them to day schools-twice to the common school-and that only one himself gave me regular instruction. In every case, too, I was for the most part turned over for what is commonly called religious instruction to Sunday school teachers,- that is to say, vain, ignorant and conceited big boys and girls,- parrots or quacks at the business.

The first of these ministers, who became my father by deputy when I was but six years old, was the pastor of a thoroughly rural parish. The surface of the country was rugged, the soil, except in small patches, poor; the farms consequently large and the settlement scattered; there was one little general store at which the weekly mail was distributed; there was no public house, but near the meetinghouse some cabins had been built with fireplaces made of field stone in which families who came from far could get warm and eat their snack between the Sunday services. (I think Sunday was then called Sunday and that the fashion of calling it Sabbath came in afterwards or had not yet reached this place.)

The accumulation of results of labor in several generations was chiefly conspicuous in the stone walls which divided the fields.

I suppose that the large family in which I lived, enjoyed more luxury than any other, but I doubt if, one year with another, four hundred dollars in money passed its hands. Every household, however, was self-supporting and none so needy that it would not resent an offer of gratuitous assistance unless it were in such neighborly kindness as the poorest might offer the richest. There was a single family of vagabond habits who sometimes came to the store and bartered small peltry chiefly for tobacco and rum, and once when they had done so betook themselves to a Sunday house and shut 


\section{Autobiographical Passages}

themselves up in it for a deliberate drunk. But even this family which was distinguished and prayed for as "the poor" kept up at least a profession of supporting themselves honestly. They probably owned the cabin they lived in and a small piece of mountain land about it. If not, I think they were the only family that did not own some land and till it.

Every one made long days' work; the parson was diligent and traveled far every week on his pastoral duties. $\mathrm{He}$ worked with his own hands a little farm from which the family living was helped out. He kept a horse and cow. He entertained a good deal of company,- - agents of benevolent societies and traveling preachers as well as family friends, parishioners and the families of neighboring ministers; but he had no hired man servant and the only maid was a young girl, probably a relative of his wife's who often sat at the table with us and before I left was married, perhaps to another minister. There was another pupil, a big boy who was reading Greek with the parson and who paid for his tutorship by helping in the farm work. On the parson's little farm we had cows and swine and sheep, turkeys, geese, fowls and bees. Besides the commoner farm crops, we raised flax and spun it. We had an orchard and sent apples to a neighboring cider mill. I remember seeing the parson grafting scions into the trees. I remember also the beating a pan when the bees swarmed, helping to pick the geese, helping to wash the sheep, setting up the martin box, going with yarn to the weavers, helping to make soap and to dip candles.

It seems to me that while I was here, though only six years old, I was under no more constraint than a man; that I went where I liked, did what I liked and, especially, that I had a hand in everything that was going on in the neighborhood. When I saw other boys going barefoot, I threw away my shoes and was no more required to wear them except on Sundays. Every house, every room, every barn and stable, every shop, every road and highway, every field, orchard and 
garden was not only open to me but I was everywhere welcome. With all their hard-working habits no one seemed to begrudge a little time to make life happy to such a bothering little chap as I must have been. Such a thing as my running into danger even from bad company would seem not to have been thought of.

I remember very distinctly wandering off by myself in the evening to the store and sitting there listening to such talk as happened; going to look in at the window of the Sunday house to see the drunken poor folks; going with boys to smoke out woodchucks from their burrows, to get rabbits in winter out of stone walls, to trap mink in steel traps and quail in figure-four traps. I remember going with rye to the grist mill, riding on the sacks behind some man or bigger boy; going at night to see a charcoal burning and then eating potatoes baked in ashes. I am often reminded of the odor that filled the air. Spending a day and night at a distant sugar camp and then sleeping in a wigwam of bark. Making pastoral visits to sick people with uncle,-so I called him though he was no family relation. I remember when a man came to say that a sick child was dead, and to get the key of the meetinghouse. I went with him and saw him strike three strokes on the iron triangle which hung suspended by strips of cowhide from the beams of the belfry by which the tidings were sent to all within hearing; and immediately women began to come from all directions to show their sympathy to the stricken parents. The loss of a single little child stirred every heart in every household. We were dismissed early from school next day and went to see the coffin made.

I remember seeing the boards stained with a red wash and varnished. We saw the grave dug and helped to take out the bier and dingy pall from the little house in the graveyard where they were kept. We walked in the funeral procession. I remember the parson's reading the usual notice in meeting the next Sunday. "It having pleased God to remove by 


\section{Autobiographical Passages}

death the infant child of Reuben and Rebecca Wilson, the afflicted parents, with the aged grandmother, the surviving children and other relatives ask the prayers of the congregation that this bereavement may be blessed to their spiritual and eternal good." As each class of the mourners was designated, they stood up in their pew, and many of the women looking on had tears in their eyes. I remember that I wondered why uncle did not pray that the child should be raised at once and brought back to her parents, and I tried it myself when I went to bed.

I remember being taken up by a sleighing party and driven far by moonlight to a large house where I saw flip made by the kitchen fire; saw the parson's girl drink it and be merry; saw romping games played around the great chimney and when finally I fell asleep, I was put to bed to be taken home in the midst of a furious snowstorm in the bitter morning by one of the boys who treated me to an upset in a snowdrift.

I don't quite see how the people old and young-even the drunkard-could be on such good terms with the parson as it seems to me they were. I certainly have seen nothing like it since. I think that the temperance reformation was just beginning and my uncle preached and prayed in the meeting, in the school and in the family against intemperance, but total abstinence was not yet insisted on. The Antislavery agitation had not arisen. Divisions on these two questions I understand were afterwards so bitter that half the congregation refused to come to meeting or to contribute to the support of the minister, who finally was obliged to ask for a dismissal on account of the extreme privations to which his family became reduced.

I learned to read in a little brown schoolhouse on the bank of a brook in the midst of the woods. I remember chestnut, hemlock, birch and alder trees about it and near by thickets of mountain laurel. The brook must have been a small one for we made a pool by damming it, into which we 
put little trout and frogs that we caught with our hands, and from which we filled the drink-water pail of the school. The ground was strewn with rocks and the brook made a crooked way among them with much babbling. I remember beds of fragrant mint along its banks and of pennyroyal on the drier roadside. Here too, by an old stone fence we drew out sassafras roots and in a marshy place at the foot of the hill we pulled the sweetflag root from the black mire.

The narrow road passed on the other side of the schoolhouse and sometimes, when wheels were heard approaching, our mistress would stop short and cry: "Your elders are coming. Make your manners! Make your manners!" and we hastened to stand in line at the roadside, the boys to bow, the girls to courtesy. Even when at play and out of sight of the schoolhouse the boys would stop and take off their hats if any much older person came near. We were eager to do it, which perhaps is to be accounted for by the fact that we saw so few people, and that no man would be in such haste or so absorbed in other duties that he could not acknowledge the courtesy and smile or say a pleasant word to us.

I was a favorite with the mistress. When she was married and was starting for the Western Reserve in a chaise with a horse-hide trunk, studded with brass nails, hung on behind, she stopped at our house to see me. She cried a little when she kissed me. Did I cry also? I think not.

I dimly recall much more that was quaint, and that it is harder to believe in, of the habits and customs of the parish, but I recall nothing that was not kindly or that I do not thoroughly respect.

One of the most incredible of my recollections is that of the serious and respectful interest taken by all classes of the people in the annual spring parade of the militia, and first that the drummer should have come to the parson for advice as he did weeks beforehand in regard to the drum head. Its renewal and the manner of it being determined, I went with a 


\section{Autobiographical Passages}

squad to a distant currier's where a sheep skin was selected, bargained and paid for in seed potatoes. After it had been prepared and mounted, the drummer and fifer practiced at the store every night, Sundays excepted, until the day of the muster.

On the Sunday before, some of the officers appeared at meeting in partial uniform. It was questioned at dinner whether this was a good custom; whether it did not minister more to personal vanity than to any good. The parson, however, regarded it as a suitable mark of respect to the house of God and remarked that the military arm of the republic had no strength except in its dependence on the Almighty. The approaching occasion was remembered in his prayers.

When the day came and the long roll was beaten in front of the meetinghouse, about fifty true yeomen ${ }^{\mathrm{I}}$ fell in and answered to their names. Nearly all wore parts of what had once been uniforms. Very few were without a black and red plume bound on the left side of their hats. The privates all had muskets, but I have an impression that the noncommissioned officers or some of them carried lances or halberds. The commissioned officers were in full military suits, not that these had been made to fit them, for I think that they had been obtained for a consideration from their predecessors and dated back to the last war. They had swords and enormous chapeau bras with plumes and also wore leather stocks and silk sashes. The company was drilled, marched, counter-marched, dismissed for dinner, reassembled and, at length, late in the day, a sergeant with a guard of honor was sent to the parsonage and the minister escorted to the ground. On his arrival he was duly saluted by the Company which then formed in hollow square, the minister, commissioned officers, "music" and the Company flag in the centre. The minister delivered a short discourse, made a long

I Mr. Olmsted was fond of the word "yeoman." This was the signature he used for his Southern letters to the Times. 
prayer and, after being thanked by the Captain, was reescorted to the parsonage. There were few inhabitants of the parish, old or young, who were not present at this ceremony, as many as possible standing, men and boys with their hats removed, on the long wooden steps of the meetinghouse at the foot of which the square had been formed.

The Company being again brought into line the Captain said a few words of compliment, closing nearly as follows:

"You are now about to be dismissed for the day and I hope that nothing will occur after the dismissal which will lessen the respect which your exemplary conduct, while under military discipline, has been calculated to inspire in the hearts of the ladies. I will only add that after the dismissal I shall give a treat at the north Sunday house which you are all heartily invited to partake of." Here a private stepped out and called for three cheers for Captain Fowler, which were given, the drum rolling and the flag waving.

In the Sunday house, pitchers, glasses, and plates of crackers, cheese and gingerbread were set out and under their influence, the earnestness which had so far characterized the proceedings gave way to a certain temperate degree of hilarity, forced and creaking.

After supper a drum and fife concert concluded the solemn patriotic festival, the last piece performed being Old Hundred.

I do not know whether it was before or after this that I spent several months with my uncle at Geneseo, where I remember being taken to see Indians making baskets, to visit at a house in the dooryard of which there was a fawn and at which a beautiful woman gave me sweetmeats, and that I was sometimes driven rapidly and silently over the turf of the bottom lands among great trees.

I was for months again the smallest boy among sixty at a boarding school, where I was placed under the special care of another clergyman, of whom I remember nothing after my father and mother drove away. Here I suffered 


\section{Autobiographical Passages}

in many cruel ways, and I still carry the scars of more than one kind of the wounds I received. I was taken away suddenly when one of the big boys wrote to his father, who sent the letter to mine, that a teacher had lifted me up by my ears and had so pinched one of them that it bled. My father had not thought of taking me away when I wrote-I think it must have been in my first letter to him-that there had been a revival in the school; that I had experienced religion, that I had had a prayer party in my bedroom to pray for his conversion and that I wished him to read a certain tract, the title of which I forget.

After this I lived for six months or more at home. But home with me had many branches, for there were no less than ten households of grandparents, granduncles and uncles in which, for all that I recollect, I was as welcome and intimate and as much at home as if $I$ had been born to them. My father's grandfather had five sons, all of whom had, I think, been seafaring men before the revolution. One had sailed in a letter of marque, was taken prisoner and died in the hulk at the Wallabout; another who was more successful than the rest in acquiring wealth and honors was carried to a peaceful grave before my day. Another was over ninety years old when I was born. I dimly recollect him, living in a large, rambling old farm house, of which he was the only occupant except his housekeeper. The fourth was also over ninety when I rode his knee. He had served the young republic both on sea and land and was the hero of a very daring and shrewd exploit, having, with three American seamen and two negroes whom he compelled to assist him, recaptured a valuable prize vessel on the high seas and brought her safely in. They were all infirm from wounds and rheumatism and I remember my grandfather out of his arm chair but once. He then walked a little way with me in a warm spring day, supporting himself with a long Malacca cane, which I now own, held with both hands. Leaning against a fence he pointed out a hang-bird's nest in one of a row of elms near us 
and then told me that he had helped his father to plant the trees, describing how small they were at the time. I wanted my father to let me help him plant trees and he did, but they were not placed with sufficient forecast and have since all been cut down. But great-grandfather's trees stand yet and the hang-birds yet have their home in them.

Then I lived for a few months chiefly with my grandmother, going irregularly to a village school, but being educated more I think through some old novels, plays and books of travels that I found in a sea chest in her garret. I actually read at this time much of Zimmerman on Solitude, Sterne's Sentimental Journey and the Vicar of Wakefield. I have the same volumes now, and I never have such a puzzling sense of double life as when I see some of Coleman's plays on the stage.

I suppose these readings developed the talent which I must have temporarily possessed two or three years later, when I could hire other boys to do my chores by telling them stories,-no doubt but partially of my own invention.

Then I spent nearly five years, vacations excepted, in the home of a minister who undertook, with God's help, to bring up four select pupils in the fear of the Lord, making no distinction between them and his own children. For their accommodation he had bought and moved a small, old country store alongside the parsonage proper, in the cellar of which he stowed cabbages and roots, on the ground floor had a workshop and harness room, and in the second story the boys' beds, desks and benches.

The clapboards were warped and shackling and the winter pressed us hard. The heating apparatus was a sheet-iron stove, if I am not mistaken made by the parson himself. The parson's salary was nominally $\$ 500$ a year but the people being poor and money scarce he took much of it in "produce"-firewood, for instance, which was invariably delivered when the sledding was good and mostly in logs. As soon as winter came, the duty was put on me to keep up the 


\section{Autobiographical Passages}

fire one day in four, and to provide wood I had to cut and split these logs, using a beetle and wedges for the larger ones; then carry the wood to the school and up stairs - all in playtime-make the fire before day and keep it up till bedtime. I was eight years old and small of my age.

The parsonage had a small back kitchen in which there was a wooden sink; outside the door stood an open water butt with a spigot at the bottom. After we had dressed by lamplight in the morning and perhaps broken a path through the snow to "the other house," we opened the back kitchen door and in turn drew water in a cast-iron skillet about six inches in diameter out of which with the aid of home-made soft soap, held at a corner of the sink in a gourd, we washed our hands and faces. A roller towel hung upon the wall for the use of all the family. On Saturday night, hot water was furnished us and we were expected to wash our ears, neck and feet. Our meals were eaten in the kitchen and here, on the bare floor, we twice a day kneeled in prayers.

The parson's son, a weakly boy who afterwards died of consumption, lived in the house with the family. The four boarder boys had the "store" all to themselves except in school hours.

They were kept in order in this way: At irregular intervals, when they were expected to be studying their lessons, the parson came to the foot of the stairs, took off his shoes, crept softly up and stood with his ear at the latch. If there was no disorder, he slipped down again and we perhaps knew nothing of his visit. If I was telling a story-my stories were generally of "run-aways" - the parson waited until I reached a situation of interest, when he would break in shouting "Oh! the depravity of human nature!" and seizing a ruler, a stick of firewood or a broom handle, go at us all pellmell over the head and shoulders.

A later biographical fragment, probably written in the nineties, carries on the story of Mr. Olmsted's education. 


\author{
H IN TS \\ AIDFUL TO ELEMENTARY \\ SELF-EDUCATION IN \\ DESIGN
}

IN THE COMMON FIELDS OF

LANDSCAPE GARDENING PROPER.

By F. L. O.

Honorary Member of the American Institute of Architects and of the Boston Society of Architects; Author of a Journey in Texas, etc.

\title{
PREFACE
}

Something accrues from special attention continuously directed for many years to a particular field of observation and reflection, giving a value to counsel about it that would not be allowed on the ground of native talent or learning on the part of the counsel-giver.

Partly for this reason I propose, by way of introduction, to give at this point some account of my life.

But partly also I propose to do so from regard to a disposition generally prevalent to underrate the value of professional or bookish counsel on the subject of this book. This disposition grows largely out of an impression that the courses by which men come to set themselves up as professional advisers on this subject or to write books upon it are, like those of students in a school, of a kind to withdraw them in a great degree from nature and from the ordinary life of men, consequently from a ready, sympathetic understanding of their wants; that these courses tend to pervert their natures, lessen freedom of mind, restrain healthy impulses and make them creatures of rules and conventions. This impression is the deeper because of the influence unconsciously 


\section{Autobiographical Passages}

acting from an old idea associated with the word garden, the essence of gardening having been withdrawal from nature and restriction to artificial conditions. (Garden, girdle and girth are from the same root-signifying constraint.) A Gardener is thought of as a man working in accommodation to artificial restrictions.

Many times something expressive of this idea has been plainly said to me or possibly said of me and of my advice and work. Hundreds of times a prejudice of mind of this nature has been apparent in those seeking my counsel.

I hope the slight account I propose to give of myself may cause what is to follow after it to be read with less prejudice of this kind than it might otherwise be.

I can see that my pleasure began to be affected by conditions of scenery at an early age,--long before it could have been suspected by others from anything that I said and before I began to mentally connect the cause and effect of enjoyment in it. It occurred too, while I was but a halfgrown lad, that my parents thought well to let me wander as few parents are willing their children should.

Within thirty miles of where they lived there were a score of houses of their kindred and friends at which I was always welcome. They were mostly farm houses and had near them interesting rivers, brooks, meadows, rocks, woods or mountains, those less rural had pleasant old gardens. Of the people two only shall be referred to particularly. One a poor scholar who, after a deep affliction, lived in seclusion with no occupation but that of reading good old books to which he had formed an attachment in happier days. One of his favorite authors was Virgil, and he took pleasure in reading and translating him to me. He was quaintly mild, courteous and ceremonious, of musing, contemplative habits, and in these and other respects so different from most men whom I knew that, as he commanded my respect and affectionate regard, I recognize him to have had a notable influence in my education. 
The other had inherited a moderate competence and been brought up to no regular calling. He lived in an unusually fine old village house with an old garden, was given to natural science, had a cabinet, a few works of art and a notable small library. He was shy and absorbed and I took little from him directly, but he was kind and not so careful of his treasures that I could not cautiously use them as playthings and picture books. He introduced me to Isaac Walton. He had no man servant,--indeed no servants, his handmaids being of the order then called help, and he was on precisely the terms with them, as it now seems to me, that he might have been with helpful sisters, though they did not sit at table with him.

A man came from without the household for the heavier work of the place, giving but a small part of his time to it, and there was a boy to do the light chores who received no wages but worked for his board, books and schooling. One of the boys who thus became my playfellow afterwards made his way through college, studied law, and came to be a member of Congress and Governor of a State.

For the rest my kinsmen and friends were plain, busy, thrifty people, mostly farmers and good citizens.

If in my rambling habits I did not come home at night, it was supposed that I had strayed to some of these other homes where I would be well taken care of, and little concern was felt at my absence; but it several times occurred before I was twelve years old that I had been lost in woods and finding my way out after sunset had passed the night with strangers and had been encouraged by my father rather than checked in the adventurousness that led me to do so.

It was my good fortune also at this period to be taken on numerous journeys in company with people neither literary, scientific nor artistic, but more than ordinarily susceptible to beauty of scenery and who with little talking about it, and none for my instruction, plainly shaped their courses and their customs with reference to the enjoyment of it. As a small boy I made four such journeys, each of a thousand 


\section{Autobiographical Passages}

miles or more, two behind my father's horses, and two mostly by stage coach and canal boat. Besides these many shorter ones. When fourteen I was laid up by an extremely virulent sumach poisoning, making me for some time partially blind, after which, and possibly as a result, I was troubled for several years with a disorder of the eyes, and the oculists advised that I should be kept from study.

It followed that, at the time my schoolmates were entering college, I was nominally the pupil of a topographical engineer ${ }^{\mathrm{I}}$ but really for the most part given over to a decently restrained vagabond life, generally pursued under the guise of an angler, a fowler or a dabbler on the shallowest shores of the deep sea of the natural sciences.

A hardly conscious exercise of reason in choosing where I should rest and which way I should be going in these vagrancies, a little musing upon the question what made for or against my pleasure in them, led me along to a point at which when by good chance the books fell in my way I was sufficiently interested to get some understanding of what such men as Price, Gilpin, Shenstone and Marshall thought upon the subject.

Rural tastes at length led me to make myself a farmer. I had several years of training on widely separated farms, then bought a small farm for myself which I afterwards sold in order to buy a larger, and upon this I lived ten years. I was a good farmer and a good neighbor, served on the school committee, improved the highways, was secretary of a local farmer's club and of the County Agricultural Society, took prizes for the best crops of wheat and turnips and the best assortment of fruits, imported an English machine, and in partnership with a friend established the first cylindrical drainage tile works in America.

But during this period also I managed to make several long and numerous short journeys, generally paying my

I According to his father's diary, Frederick began the study of engineering with Professor Barton of Andover, Mass., November 20, 1837. 
expenses by writing on rural topics for newspapers. As it would have been an extravagance otherwise, however, I first crossed the Atlantic in the steerage of a sailing vessel, and nearly always traveled frugally. In all these tours I took more interest than most travelers do in the arrangement and aspect of homesteads and generally in what may be called the sceneric character of what came before me.

The word sceneric flows from my pen unbidden and I venture to let it stand. Some writers of late are using scenic for the purpose it serves, but this is confusing, scenic having been so long used with regard exclusively to affairs of the drama.

All this time interest in certain modest practical applications of what I was learning of the principles of landscape architecture was growing with me,- -applications, I mean, for example, to the choice of a neighborhood, of the position and aspect of a homestead, the placing, grouping and relationships with the dwelling of barns, stables and minor outbuildings, the planning of a laundry yard and of conveniences for bringing in kitchen supplies and carrying away kitchen wastes, for I had found that even in frontier log cabins a good deal was lost or gained of pleasure according to the ingenuity and judgment used in such matters; applications also to the seemly position of a kitchen garden, of a working garden for flowers to be cut for the indoor enjoyment of them, to fixed outer floral and foliage decorations, to the determination of lines of outlook and of in-look and the removal or planting accordingly of trees, screens, hedges, windbreaks and so on, with some consideration of unity of foreground, middle ground and background, some consideration for sceneric effect from without as well as from within the field of actual operations. I planted several thousand trees on my own land and thinned out and trimmed with my own hand with reference to future pleasing effects a small body of old woodland and another of well-grown copse wood.

Never the slightest thought till I was more than thirty 


\section{Autobiographical Passages}

years old had entered my mind of practicing landscape gardening except as any fairly well-to-do, working farmer may, and in flower gardening or of any kind of decorative or simply ornamental gardening - any gardening other than such as I have indicated-I was far from being an adept.

But I gradually came to be known among my neighbors and friends as a man of some special knowledge, inventiveness and judgment in such affairs as I have mentioned, and to be called on for advice about them. At length, growing out of such little repute, I was unexpectedly invited to take a modest public duty and from this by promotions and successive unpremeditated steps was later led to make Landscape Architecture my calling in life. . . .

I have since, partly on professional and partly on other occasions, continued to travel a great deal. . . . But a small part of my journeyings either in the old or the new world have been made by railways. I have traveled several thousand miles on foot and several thousand in the saddle and I have had rare opportunities for seeing people of all sorts in all parts of our land in their homes.

All the time interest in scenery, landscape, landscape architecture, has been strong with me.

Through these causes and because of the interest I have thus explained I have been much led into pointed conversations with men and women under a great variety of circumstances, while looking about their abodes or while following their chosen paths, roads and waters, with regard to the pleasure to be had in doing so and with direct reference to means of enhancing it or getting the better of circumstances restricting it. 


\section{CHAPTER II}

\section{EARLY PLEASURE TOURS}

IN connection with the tours for the enjoyment of scenery which young Frederick Olmsted made, generally with his parents, it is perhaps interesting to record in detail one taken in I838, when he was sixteen. His father, Mr. John Olmsted, kept an accurate diary, and in this we find noted: "Journey to White Mountains," "in our double carriage," "self, wife, Fredk. and John," Aug. 8-25, I838. The itinerary reads:

"Springfield, Mt. Holyoke, Northampton, Whateley, Deerfield (old houses), Bloody Brook, Greenfield, Bernardstown, Brattleboro, Putney Hills, Walpole, Bellows Falls, Charleston, Claremont, Windsor, Hanover (view of river from hill), Orford, Haverhill (N. H.), Newbury (Vt.), Oxbow Narrows, Bath, Franconia Notch, Mt. Lafayette, Littleton, Fabyan, Crawford Notch, Conway, Center Harbor, Lake Winnipesaukee, Red Mt., Wolfboro, Rochester, Great Falls, Dover, Portsmouth, Newburyport, Haverhill, Andover, Lynn, Nahant, Boston."

In Boston there is a note: "Navy Yard, Bunker Hill, Mt. Auburn, Athenæum," Aug. 22 "F. to Andover."

Frederick's voyage to China before the mast in 1843 gave little opportunity for pleasure sightseeing, and while lying in the ports of Canton and Hongkong,-if we may judge from the few notes he has left about this experience,--he was naturally most interested in the people and their strange customs and their attitude towards "heathen" visitors.

There are two of Frederick's letters relating to trips in the summer of 1845 .

\section{Glen Falls (N. Y.), Aug. 3, I 845 .}

DeAR FAther: or whoever is at home, if Father has gone to Saratoga:

I believe the only description of the country between here and Burlington $I$ have given you was in a pencil letter written 


\section{Early Pleasure Tours}

at Charlotte. The afternoon's ride of that day was through a very poor country, clay and stones. What land had been cleared seemed to be principally devoted to the raising of burnt stumps and mullen; some little grass, to be sure did now and then make its appearance, but I should think the poor sheep would find it hard work enough to live, without troubling themselves with growing wool. A little ways out of Charlotte, though, I recollect I was met by one of the finest views I had ever seen. It was on a hill which overlooked the country and the lake towards the southwest. Between me and the Lake lay some pretty village or other on the ground sloping towards it, the land looking really very rich,- - and by the way the soil just by the lake all along is fine. Beyond lay the Lake itself,--bays, islands, etc.,-looking beautifully; but the chief charm was the background, a heap of mountains over in Essex Co. I never saw mountains rise more beautifully one above another, the larger ones seeming to cluster round and protect the smaller, nor did the summer veil of haze ever sit on them more sweetly. Back of all rose some magnificent thunder-heads and they rose fast too, compelling me at five o'clock to take refuge and toast and eggs in a little road-side inn.

\section{“HARTFORd, Sept. I, I 845.}

\section{"My deAR Fred [Kingsbury]":}

Charley and I had a fine cruise 'round. Charley wanted to get home before Emma left, and we drove, with all night

I This letter, written to one of his chums, refers to a sailboat trip from New Haven to Hartford, with Charles Loring Brace, another of the group of five young men formed during the New Haven days (John Hull and F. L. Olmsted, Charles Trask, and the two just mentioned). In a reminiscent letter Frederick Olmsted says of Charles Brace: "We had many long tramps together; I remember once being with him for a week or two on a walk which took us through Litchfield, Stockbridge and Lenox. I remember also vividly a fine run of fourteen miles on skates, ending in a cold bath. He entered college with my brother and they were room-mates; and, as for four years afterwards I lived in or near New Haven, and was, a part of the time, attending the same lectures with them, we continued to be in close intimacy." 
sleeping in a boat or on the ground, and one night on a sloop's transom. Sunday night we camped out at Haddam, below. Made a sq. sail of our tent, and turned in on a blanket under it. It was a most beautiful place, a green grassy dell glen sloping gently up, lofty and picturesque trees opening a way for it back to a most lovely vista. A most charming prospect of our Rhine in front and on either side. Lots of wild pigeons, meteors, owls, sturgeons, mosquitoes, wipporwills, methodists, and hydrophious quadrupeds to lull us to grassy sleep. We struck our tent and broke up camp at an hour or two before day break, and were till noon working up to the landing a few miles above. I believe you will think we didn't do much at Mineralogizing. We went with John and Rev. Mr. Gilbert to the mines-a rocky hillside, and in an hour or two got a pocket full of tourmalines, garnites and something else (?) and appetites and a glass of brandy for my cholic, because we were too lazy to kindle a fire Sunday morning and eat green apples to kill-hunger.

Both Frederick Olmsted and his brother were fond of boating, and, in their small sail-boat, had many trips on the Connecticut River and in the Sound, especially during the family's summer visits to Sachem's Head. In spite of the harshness of his experiences on the Chinese voyage, $\mathrm{Mr}$. Olmsted retained his fondness for ships and was wont to hold up the clipper ship as the ideal of beauty in perfect organization for use.

There is also a reminiscence jotted down in Mr. Olmsted's later days of a trip to Canada in $\mathbf{I} 846$.

Once on a time my father took me with him on a journey which carried us into Canada. While there we had for several days as a traveling companion an Englishman, animated, amiable, frank and engaging. As I think of our intercourse now, I can see plainly that he looked upon me as a new specimen and was drawing me out and turning me over with the interest of a naturalist. It is clear also that he got some new ideas from me and often when our conversation was inter- 


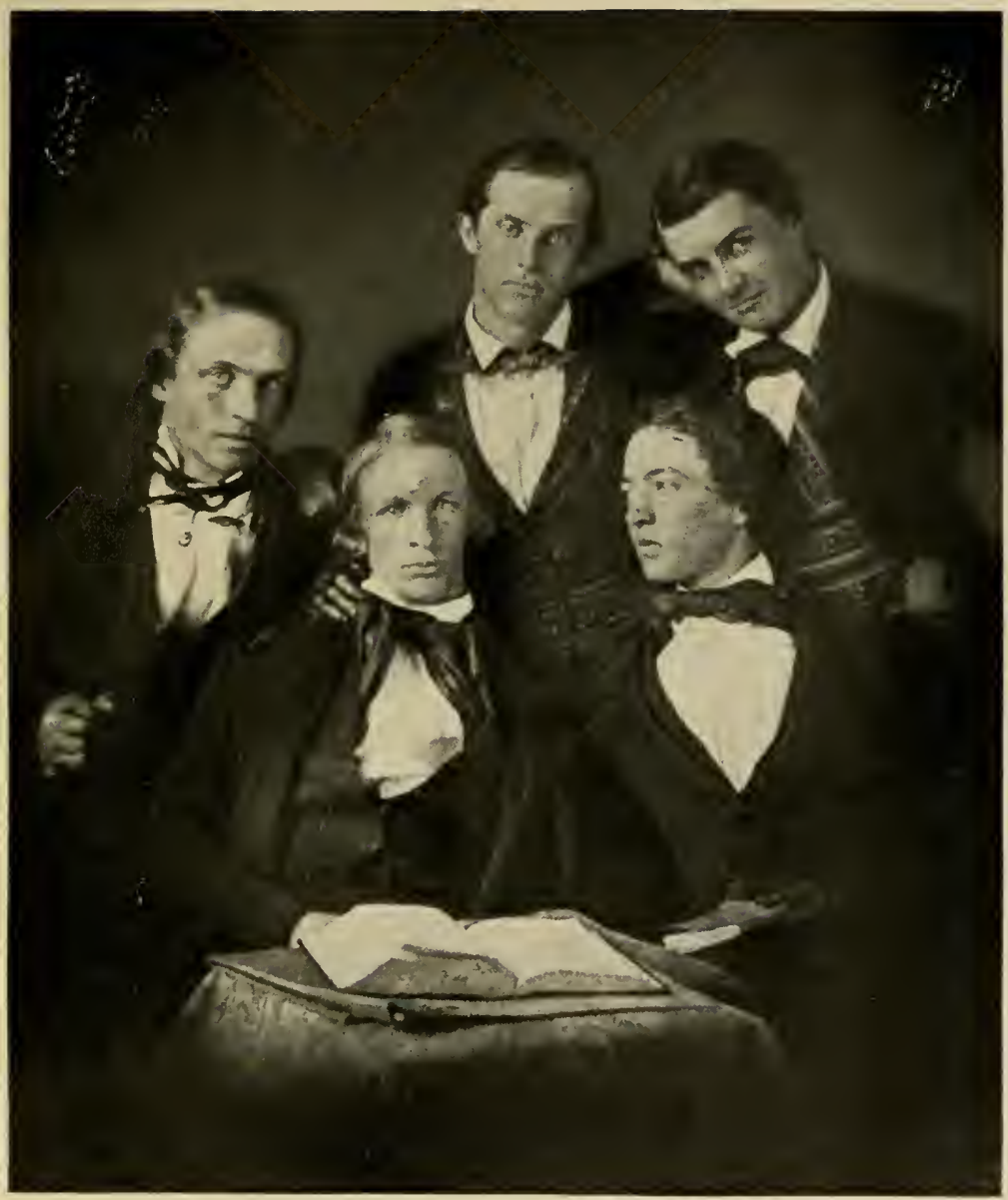

The Five Friends in New Haven Days

Charles Trask

Frederick J. Kingsbury

John Hull Olmsted

Charles Loring Brace

Frederick Law Olmsted 



\section{Early Pleasure Tours}

rupted, he took notes. My experience with men in America, though I was a youngster, had been various, and I was then fresh from association with a large number of youngsters,youngsters merely, but gathered from all parts of the Union. With these $\mathrm{I}$ had been made intimate at foot ball and boat club, in long walks, trouting excursions, duck shooting, long winter night talks over the stove and more formal debates of our "Society." My experience of mankind and my views of men were crude and bigoted, but they were obviously sincere and simple convictions and they were as strange to the Englishman as average English country-gentlemen's convictions would surely be to me. 


\section{CHAPTER III}

\section{STUDY AND READING}

AgaIN in the nineties, when Mr. Olmsted was thinking over and analyzing his early experiences in their effect on his subsequent professional work, there is a letter to an old friend, a lady, which shows especially his turn of mind in youth and some of his self-chosen readings:

I am thinking that of all the young men you know, I was the least likely to do what I have, and that you cannot know or guess in what way I was led to it. Nor can you know what is most prominently in my mind when I refer to these doings. I need not conceal from you that I am sure that the result of what I have done is to be of much more consequence than any one else but myself supposes. As I travel, I see traces of influences spreading from it that no one else would detect, which if given any attention by others, would be attributed to "fashion." There are, scattered through the country, seventeen large public parks, many more smaller ones, many more public or semi-public works, upon which, with sympathetic partners or pupils, I have been engaged. After we have left them, they have, in the majority of cases, been more or less barbarously treated, yet as they stand, with perhaps a single exception, they are a hundred years ahead of any spontaneous public demand, or of the demand of any notable cultivated part of the people. And they are having an educative effect perfectly manifest to me-a manifestly civilizing effect. I see much indirect and unconscious following of them. It is strange how often I am asked: "Where did you get that idea?" as if an original idea 


\section{Study and Reading}

on the subject had not been expected. But I see in new works of late much evidence of effects of invention-comprehensive design; not always happy, but symptomatically pleasing. Then I know that I shall have helped to educate in a good American school a capital body of young men for my profession,--all men of liberal education and cultivated minds. I know that in the minds of a large body of men of influence I have raised my calling from the rank of a trade, even of a handicraft, to that of a liberal profession, an art, an art of design. I have been resolute in insisting that I am not to be dealt with as a mere agent of my clients, but as a councillor, a trustee, on honor. I have always refused to take employment on other terms, and when it has appeared that I must do so or yield the point, I have seven times already resigned the charge of important and interesting works. It is what I have done in these respects, and what I see of the indirect effect on the standing of my profession and the progress of my art, that leads me to write to you after so many years, in the self-complacent way that I do. This, rather than anything you have seen, or of which you have read.

I was saying that of the young men, comradic young men, that you knew, I was the last to have been expected to lead such a life as I have. I was strangely uneducated,-miseducated. Because of an accident putting my eyes in some peril, I was at the most important age left to "run wild," and when at school, mostly as a private pupil in families of country parsons of small, poor parishes, it seems to me that I was chiefly taught how not to study,- -how not to think for myself. I tried to learn Euclid by rote, without trying to understand what it meant. While my mates were fitting for college, I was allowed to indulge my strong natural propensity for roaming afield and day dreaming under a tree. The year before John entered college, I went to sea before the mast. It was soon after my return from China that I first met you and you lifted me a good deal out of my constitutional shyness and helped more than you can think 
to rouse a sort of scatter-brained pride and to make me realize that my secluded life, country breeding, and miseducation were not such bars to an "intellectual life" as I was in the habit of supposing. Or, if this is too personal, let me say that, through visiting at your house the first winter I was at New Haven with John, I was given a turn, not to study, but toward an "intellectual life" to which I feel that nearly all that I have been saying complacently of my doings is to be remotely attributed. You will smile of my thinking of you at all as a mentor, especially in a literary way, if you remember a certain Christmas present that you gave me: (It was burned thirty years afterwards with some heirlooms, autograph letters of Washington and Webster and other treasures). But in some way in which you had to do, I was led up at that time to Emerson, Lowell and Ruskin, and other real prophets who have been familiar friends ever since. (Here they are on my bed-table). And these gave me the needed respect for my own constitutional tastes and an inclination to poetical refinement in the cultivation of them that afterwards determined my profession. Yet that is not quite fair, for I had had two lifts in the same direction before. One, when I had heard my father reading the books of travel in New England of President Dwight, Professor Silliman and Miss Martineau, in all of which the observations on scenery with which I was familiar had helped to make me think that the love of nature, not simply as a naturalist but as a poet loves it, was respectable. The other, when, yet a boy, I found in the Hartford Public Library certain books, which it is a strange thing that I should have looked into; stranger that I should have assimilated as much as, when re-reading them perhaps twenty years afterwards, I found that I had. They were Price on the Picturesque and Gilpin on Forest Scenery,-books of the last century, but which I esteem so much more than any published since, as stimulating the exercise of judgment in matters of my art, that I put them into the hands of my pupils as soon as they come into our 


\section{Study and Reading}

office, saying, "You are to read these seriously, as a student of law would read Blackstone."

Of Mr. Olmsted's early reading we have several accounts in letters written at the time.

There is a letter to Fred. Kingsbury in which Fred. Olmsted enumerates "Books to Read."

Moral Philos: "Butler's Sermons," (recommended by Dr. Chalmers, Sir James Mackintosh, Arnold, Pycroft and others). In place of it, "Sewell's Chstn. Morals"; "Abercrombie's Philos. of Moral Feeling" (brief and comprehensive); "Foster's Essay on Decision of Character." Mental PHILOs: "Abercrombie on the Intellectual Powers, and the Investigation of Truth"; "Combe's Constitution." PolitICAL PHILOS: "Miss Martineau's Tales," (I suppose they are to Polit. Philos. similar to Historic Novels to History); "Whately" [Richard]; "M'Culloch's Principles"; "The Encyclopedia " (Rent, tax, etc.); "Jefferson"; "The Federalist, etc."; ART: "Abstract of Sir Josh. Reynolds' discourses"; "Abstract of Pilkington's Lives of Painters"-(Visit collection in compy. with an artist); "Allan Cunningham's British Painters"-Sculpture--Encyclopedia. BRITISH HISTORY: "Socy. for Prom. Chstn. Knowledge"; "Miller's Life of George III"; "Lives of George IV and Wm. IV"; "History of British India"; "Basil Hall"; "Macaulay."

I say nothing about Poetry or Fiction or Ecclesiastical Literature. I've read enough already to choose from to read over again without going wrong, and I presume I can read back to better advantage than I can read ahead. I say nothing either about Agriculture or Law-I have a course in each laid out. I expect to read on Geology, Mineralogy, and Anatomy before long and Nat'l History generally as I have opportunity or inclination.

I'll thank you to give me any advice suggested to you in reading the above. I have left out "Cobbett's Grammar," "Whately's Rhetoric and Logic." I have read "Burke on 
Taste" and your Rept. of Prof. Lardner's Lecture. I should like to find more of those comprehensive Lectures on such subjects. Prof. Lardner's Lectures are brief and comprehensive and very well adapted to give a simple man a common information in regard to Natural Science and Mechanics. You must have been bored with this letter but I expect you to answer it becomingly.

It must have been earlier than this that he attended with Charles Brace "a private course of lectures on architecture."

From I845, Mr. Olmsted's main study centered in agriculture. From "Fairmount," Mr. Geddes's farm, he wrote to his father June I6, I846: "Farmer's Lib. \&c I received Monday. I am glad they are going to publish the Book of the Farm next. I had hoped they would. It is a cheap way of getting it. English price is I think \$20."

Again on Aug. I2, 1846, he wrote:

I have been looking for a letter from you and the Monthly Journal for two or three days. I am anxious to hear about the Head Farm. If the Farmer's Library can be had separately at half subscription price, I would drop the Monthly Journal though it is very good, in favor of Drs. Emmons and Prime's Quarterly Journal of Agriculture and Science, a very able, practical, scientific, periodical, \$I.50.

"I have thought of writing an article about Fuller's Farming, etc. for the Cultivator, but have given it up because I have not myself sufficient reliance on the correctness of statements.

The same year he wrote to Fred. Kingsbury: "I am reading now everything on Horticulture and Pears and Arnold's life and correspondence-I always loved Arnold - and pears."

From Guilford, Connecticut, February 16, I847, Frederick wrote his brother John: "Tell Father I want the Horticulturist, etc. Nothing here but the Boston Cultivator."

On a visit to New York City in October, 1847, he mentioned spending a forenoon "at Colman's," who has "a beautiful new portfolio of sketches in Holland and Belgium, 


\section{Study and Reading}

mostly interiors. They are very fine" . . . "lots of fine things of course - two finer than I ever saw of Landseer" "I bought a number of books, cheaply at the auctions."

After his father purchased for him the farm on Staten Island, he began to think of a rounded-out collection of his own. We find him writing to his brother: "There are a lot of books that are essential to even a common library-or a country tavern parlor-that I have not got. Such buy if you can, without fail."

The young farmer thought also of decorating his walls, and wrote to his father about pictures (March 9, 1848): "You said I could have a lot out of the portfolios; I should be exceedingly glad if you could spare me some frames." The "portfolios" doubtless included the one which Mr. Olmsted referred to later in life in a reminiscent jotting:

The first portfolio of prints that I ever saw was a possession of my childhood and was a series of views of English park scenery. Chance soon after put in my hand Gilpin's Forest Scenery and Gilpin's and Marshall's Tours and criticisms of parks. I have been studying the subject ever since.

In February, I849, Frederick mentioned in a letter to his brother John that he had been reading and discussing Modern Painters, for which he always continued to have a high regard. Later in the month he referred to one of the subjects in which he was then principally interested as "Landscape Beauty and the Beauty of all Nature." His tastes were varied, for he mentioned also several other miscellaneous subjects including the "Theory of Language" and the "Theory, Economy, etc. of Love."

On his English tour in I850 he acquired a number of works on agriculture and gardening, of which unfortunately we have no specific record; and after his return he wrote over to one of his travelling companions Charles Brace, still abroad: "I want you to get or order in London in addition to what I asked previously: Morton on Soils (up to \$2.), Hutchinson on Spring Draining (not over \$2.), Herwit Davis on Thin Sowing (a pamphlet), Prof Johnstone's Tables of Experiments in Agriculture (a pamphlet, very important)."

Mr. Olmsted's own book Walks and Talks came out in I852. On a bill ( 1852 ) from G. P. Putnam \& Co., Publishers 
and Importers, including several copies of Walks and Talks evidently purchased for gifts, are listed also: "I Pencil Sketches," "I Smith's Parks and Pleasure Grounds," "I Am. Farmer," "I Caird's Agriculture," "I Miniature Fruit Garden," and "I Agricultural Survey."

It is a great pity that the library collected by Mr. Olmsted during his career as a farmer and later as a writer, and during the first years of his work as a landscape architect, was practically all burned in the winter of $1863-64$ after his departure for California. Regarding this calamity, he wrote a friend:

"Since I left New York all my household goods including a library with a number of rare technical books which I got in Europe and can never replace have been destroyed by fire."

The books were stored at the Staten Island farm in an outbuilding, thought to have been maliciously fired. 


\section{CHAPTER IV}

\section{FARMING}

Following his taste for outdoor life, and with the approval of his father, Frederick Olmsted determined to become a farmer at the time his brother was determining on a doctor's career if his health permitted. It was through their friend Frederick Kingsbury that Frederick Olmsted was directed to the farm of Mr. Joseph Welton in Waterbury, where he began the serious study of agriculture in May, $1845 .{ }^{\mathrm{I}}$

In June of that year he wrote to Charles Brace from Waterbury:

For myself I have every reason to be satisfied with my prospects. I grow more contented or more fond of my business every day,-really, for a man that has any inclination for agriculture, the occupation is very interesting, and if you look closely you will be surprised to see how much honorable attention and investigation is being connected with it. The Cultivator has now five regular monthly European correspondents. Scientific men of highest distinction are there devoting their undivided attention to its advance; and I think here, the coming year will show a remarkable progress.

A day or two later Frederick wrote his brother John:

For my part I believe that our farmers are, and have cause to be, the most contented men in the world; and for the matter of profit, it is sufficient to know that they live and

I This was a period of intelligent interest in scientific agriculture, and there was an outburst of farm journals, beginning in the late thirties. See the list in Bailey's Cyclopedia of American Agriculture, I909, Vol. IV. 
bring up their families in what they consider comfortable circumstances, with the usual system and management. I should think by the use of the proper tools and machinery which a man of intelligence and information could procure and invent, at least half of the most disagreeable and hard labor of our old-fashioned farmers might be dispensed with to advantage. But I doubt whether taste for its peculiar pleasures, or inclination or ability for its manual exertions, will make you a farmer. If you could, however,-and of this you are the best judge,--become interested in its operations for a year or two, and connect yourself with its present rapid advance as an honorable and learned profession, you would not only find it a sufficient means of support, but an agreeable and healthful pursuit.

From notices in farm journals, such as the Cultivator, Frederick Olmsted was led to select the farm of Mr. George Geddes called "Fairmount," near Owego, N. Y., as the place to pursue further his apprenticeship in agriculture, since Mr. Geddes $^{\mathrm{I}}$ had been awarded first prize for the best-ordered farm in New York State.

On March 19, 1846, Frederick wrote to his brother from Hartford:

I shall start I think directly after the election, I presume going to Albany first, and then on west to Syracuse, etc., with letters from Mr. Norton and Tucker of the Cultivator. Father has obtained I 5 new subscribers for the Cultivator here. ${ }^{2}$ Perhaps, and I should prefer to, come per New Haven and N. Y. and first with Professor O's letter to Owego. Please do say what you think about it. I should like to make

I "Mr. Geddes' father was prominent in building the Erie Canal and he was himself an engineer, as well as a farmer, and interested in politics, so that Mr. Olmsted had plenty of stimulus to think while he worked, and in the evening to discuss a wide range of subjects with an intelligent man." From Biographical Introduction by F. L. Olmsted, Jr., to Seaboard Slave States, edition of 1904 .

${ }^{2}$ Mr. John Olmsted's firm in Hartford was a regularly accredited agency for the Cultivator and its name appcars on the title-page. 


\section{Farming}

you a visit again before I go for good and I shall probably spend next winter on [the] farm.

In June he wrote to Frederick Kingsbury from "Fairmount":

I want to make myself useful in the world, to make others happy, to help to advance the condition of Society, and hasten the preparation for the Millennium, as well as other things too numerous to mention.

Now, how shall I prepare myself to exercise the greatest and best influence in the situation of life I am likely to be placed in. You know perhaps as well as I what that is-I suppose it's not very great stretch of ambition to anticipate my being a Country Squire in Old Connecticut in the course of fifteen years. I should like to help then as far as I could [to foster] in the popular mind generosity, charity, taste and etc.,-independence of thought of voting and of acting. The education of the ignoble vulgus ought to be much improved and extended.

The Agricultural Interest greatly preponderates in number and wealth in the state, but perhaps has the least influence in Legislation. Lawyers whose sense of right and truth is blunted by profession-the sense of law-and traffickers who value themselves as they can make their own interest appear-whether truly or not-the interest of another, make our laws, make public opinion, because they have had their intellectual faculties sharpened by practice and education. Now the people-farmers and mechanics-the producing classes that the rest live on-want to think and judge for themselves, to cultivate the intellectual.

There is happily a reminiscence written by Mrs. Frederick Law Olmsted in $1920^{x}$ of her husband's establishment on his own farm at Staten Island and of the meeting of the Olmsted and Perkins families.

${ }^{3}$ Mrs. Olmsted died April 23, I92I, at the age of ninety-one. 
"In the summer of $1847 \mathrm{Mr}$. John Olmsted of Hartford, Conn., was staying, with his family, at the Sachem's Head Hotel where he met Mr. John Bowne of New York. Mr. Bowne's wife was the daughter of Dr. Akerly late of Staten Island, whose family were desirous of selling the farm left by Dr. Akerly. Mr. Olmsted and his son Frederick, being dissatisfied with the prospect for success in the small farm at Guilford, bought not long before for Frederick, accepted Mr. Bowne's invitation to go to Staten Island, South Side, and inspect the Akerly farm. Their impression was so favorable that Mr. Olmsted bought the place, I30 acres, paying for it $\$ 12,000.00$ and took possession the following winter. The farm stretched from the Main Road to the shore of Prince's Bay about a mile in length.

"Leaving the main road one entered a very pretty wood of trees of fair size,-oaks, maples, sweet and sour gum, sassafras, holly, etc. After about a quarter of a mile one came out upon the cleared land on the top of a small rise. The soil was heavy red clay, very suitable for wheat, etc., yielding up to 40 bushels per acre. There was a sort of plateau from which the land sloped gently down for about quarter of a mile and then an almost level stretch went to the bank six feet above the beach. From all this part of the farm there was a fine view of Prince's Bay looking across to Sandy Hook (slightly foreshortened), Navesink, and the New Jersey Hills stretching away to the southward. There were no trees on this level with the exception of one tall old pear tree at the foot of which were found from time to time the bones of the slaves who had been buried there. . .

"The farm commanded a view of all shipping outward or inward bound. ...

"The house, standing at the foot of the slope, was built of rough stone plastered over with lime, and had been, until shortly before Dr. Akerly's death, only a story and a half high. He had, in order to accommodate his growing family of grand-children built on in wood a full story and a half, giving nine bed chambers. Outside the junction of the stone and wood was disguised by the roof of an all round piazza. Inside the effect was rather odd for the stone wall a foot and a half thick came up nearly three feet and on top of it were built closets convenient, but queer. Downstairs was an entrance hall of $12 \times 16$ feet going through from east to west and on each side a $16 \mathrm{ft}$. square room with tolerably high 


\section{Farming}

ceiling, windows with deep seats looking east and in one room a window looking south either side of the fireplace.

"On the south end, the ground sloped so that there was an easy entrance for barrows to the cellar, large and well lighted, and used as a dairy. There was a small outbuilding north of the house where was found a breast plate engraved 'The King's American Dragoon's,' laid away on a beam in what had evidently been a stable.

"The first time I ever saw Frederick was in February of I 848 when he came over to Holly Hill to tell Grandpa Perkins the news of the flight of Louis Philippe from Paris, just received in New York.

"Frederick was then settled on his farm with his Aunt Maria Olmsted as housekeeper and provider for two jolly green freshly imported Irish maids and three or four farm laborers. We soon called on her and the families were very friendly. At that time Grandpa occupied Holly Hill Farm and Uncle Frank was living in South Brooklyn. John Hull Olmsted had just graduated and had come to New York to Dr. Willard Parker's office to study medicine. He came to the farm for week ends and holidays bringing Charles Brace generally and sometimes Frederick Kingsbury. By the winter time I had grown so intimate with the Olmsteds that it was arranged that I should pass Christmas at Hartford on my way back from a visit in Boston, which I did.

"In June his father, step-mother and half sisters Mary and Bertha and young half brother Albert came to pass a long season, bringing with them a fine span of horses and an open carriage, the regular farm outfit being Old Black subject to blind staggers and not too speedy at best and an old Rockaway.

"Frederick was at this time 26 years of age full of life and fun. He threw himself into farming with enthusiasm, introduced system and order to his men, expecting for one thing that at knocking off time every tool used should be returned to its appointed place and that every 'chore' should be done at the hour fixed, the foreman to report progress before going in to supper. He engaged in planting and dealing in fruit-trees, pears principally, which he imported from France. All was done in a simple inexpensive way, using the old buildings on the place and practicing rigid economy. $\mathrm{He}$ interested himself in the County Agricultural Society and soon became an active member in company with Wm. H. 
Vanderbilt who was at the time a farmer at New Dorp Lane.

"Frederick had a very pretty talent for caricatures, not of a grotesque kind but full of quiet humor. . . . He was fond of long discussions on moral points as when, if ever, it is allowable to depart from a direct statement of fact, etc., etc. He was perhaps over fond of arguments to be pleasing to women. Whimsies had no charm for him. Sartor Resartus and Modern Painters were our text books.

"Aunt Maria was a dear kind devoted woman of fifty, plain as a pikestaff and devoid of vanity.

"Mr. Olmsted, the father, had just retired from business with a modest competence. He was the kindest and most indulgent of fathers, - a man with a strict sense of justice and of duty, exacting toward himself rather than toward others. His wife was a Puritan, a model of order and system, most efficient as an organizer and full of interest in Nature and Man.

"The family continued to make its summer home at the farm until the end of the summer of 1853 , six years."

It was in $1849-1850$ that Frederick considered going into the nursery business on a small scale. He wrote to his father on March 14:

I have been to Flushing and got the trees. Parsons' bill is $\$ 258$. and he desires especially if it cannot be paid before the Ist of May that he may have paper that he can use-your note. I have been so unfortunate in my sales that I concluded not to take so many by 300 trees as I had intended. Parsons being very willing, he will probably sell the trees from 5 to Io per cent more than my price. Mr. Field strongly recommends me to purchase for myself in France. Thinks I might find ready sale for some thousand on Staten Island within a few years, at Ioo per cent over cost of importing them. I called at the Packet offices this morning but could not get anything reliable as to freight. As near as I can guess the bulk of 100 trees (small dwarf pear) of ordinary goods would not be over $\$$ I.Oo. S- gave me to understand it would be near \$IO. I think he lied. But even at that I could 


\section{Farming}

import them one year younger than these I have of Parsons for but little more than one half what I pay him and at about one quarter what Mr. Field paid for his.

Later in his venture he wrote to Fred Kingsbury:

South Side, Dec. 2I, I850.

There is a good deal of building this winter.

My trees are to arrive soon, so I cannot go to Connecticut at present. More of them than I had calculated the man could supply, about 5,000 pears. The nurseryman makes me a present of 200 samples of his shrubs and trees. They are also lower than they had been offered and promise very fine. You have a nurseryman in Waterbury. I wish you would ask him if he does not want some pears on pear or quince stock, of the latter I have the finest lot ever imported and will sell them lower than the regular nurserymen. I shall have a few popular shrubs and trees of other sorts. How would a few hundred go at auction in Waterbury? I have a lot of (pot plants) cedar of Lebanon.

In this letter, he adds:

We are likely to have a Plank Road upon the island, contract is offered at exactly the sum per mile I estimated in an article upon the subject in the Staten Isler last spring. Our society does well, I have near $\$ 20$. worth of premiums.

The society to which he refers, and of which he was Corresponding Secretary, was the Richmond County Agricultural Society. Early in $185^{\circ}$ the Board of Managers issued an "Appeal to the Citizens of Staten Island." In this we read:

"How is this, Fellow Citizens? Is the very best method of Farming which can be adopted universally practiced among us? Is it by any one of us? Is Agriculture, as a science, sufficiently understood in our community? Can no 
luxuries be added to our orchards - no new beauty bloom in our gardens? Are there no incongruities or inconveniences in our Domestic Architecture? Is the want of refined Rural Taste nowhere observable on our island? Are we quite satisfied with our Roads-confident that our breeds of cattle are unsurpassed, and that no improvements can be added to the implements of our Husbandry, that we should neglect or refuse to combine our knowledge and influence in these matters? May we not want a little of the patriotic sentiment, the neighborly feeling, the cordial good understanding among ourselves, that would be promoted by a free interchange of our thoughts, opinions and observations, and by manifesting a unity of purpose with regard to these subjects of common interest?"

Frederick recorded his progress in the nursery business in a letter to his father Nov. 6, I851 :

I have sold near \$100. worth of trees besides those sent to Terry. Received order for a small lot to be delivered at Hartford at wholesale prices from Sol. Porter, Porter Place, Banker. I referred him to my letter but told him that on the supposition that he meant to increase his order I would send the trees, putting them on board Hartford boat at $\$ 50$. rate, if I did not hear from him this week to the contrary. $\mathrm{He}$ ordered also some peach trees, which I shall have to get, I don't know where. Next day another order, " 2 d, not for Porter Place," for 20 more pears. I have had two calls from men that wanted a large number shade trees-evergreensand other fruit trees, that I could not supply-and could not get the ordering of. One of them ${ }^{\mathrm{I}}$ is engaged in laying out grounds for Aspinwalls, Livingston and others at Clifton and told me he should have bought a good many hundred trees if I had had such as he wanted. He took $3 I$ pears at 60 cts. for Livingston and O'Conner. Townsend called \& took 24, Bunker, I 5 and others of that sort, making the best sort of nest eggs for the business.

"Evidently one of the popular "landscape gardeners" to which reference is made in Part III. 


\section{Farming}

There is a remark in a letter of 1890 from $\mathrm{Mr}$. Olmsted to Dr. Peter Collier, Director of the Agricultural Experiment Station at Geneva, N. Y., which shows how important he considered this period of his career: "I began life as a farmer, and although for forty years I have had no time to give to agricultural affairs, I still feel myself to belong to the farming community, and that all else that I am has grown from the agricultural trunk." 


\section{CHAPTER V}

\section{LANDSCAPING}

THERE are several bits in the letters during his career as a farmer that show his earliest attempts at landscape improvement.

When the farm at Sachem's Head, Guilford, was being considered for purchase, he wrote to his father, July 23,1846 :

I have thought a good deal about that Sachem's Head place without knowing it was for sale (so I have of 'Miah's). There is no fruit there, I suppose, and perhaps no soil for it. I should like to hear more about it. There is the prettiest ground for a ferme ornée in that place of 'Miah's I ever saw almost, a beautiful nook under the mountain or dell, with a fine large trout brook running through it, a quarter of a mile from David's, half a mile from the railroad canal. The farm has been miserably cultivated by the old miserly tyrant that has gone to his account, but there is by nature excellent land and every convenience and beauty desirable.

After the Sachem's Head farm was bought, he wrote definitely (March 23, I847) of its landscape development to his brother, with a marginal sketch of his general idea:

I wrote shortly to father yesterday and now reply to yours of the 18 th inst.

I note what you say about Alsop's and trees. I intend to plant (trans-) but few ornamental trees and with them to take great pains, - until I know where to put my house exactly, I cannot arrange the lawn very well. The lawn is to be the grand feature of my gardening. The ground is 


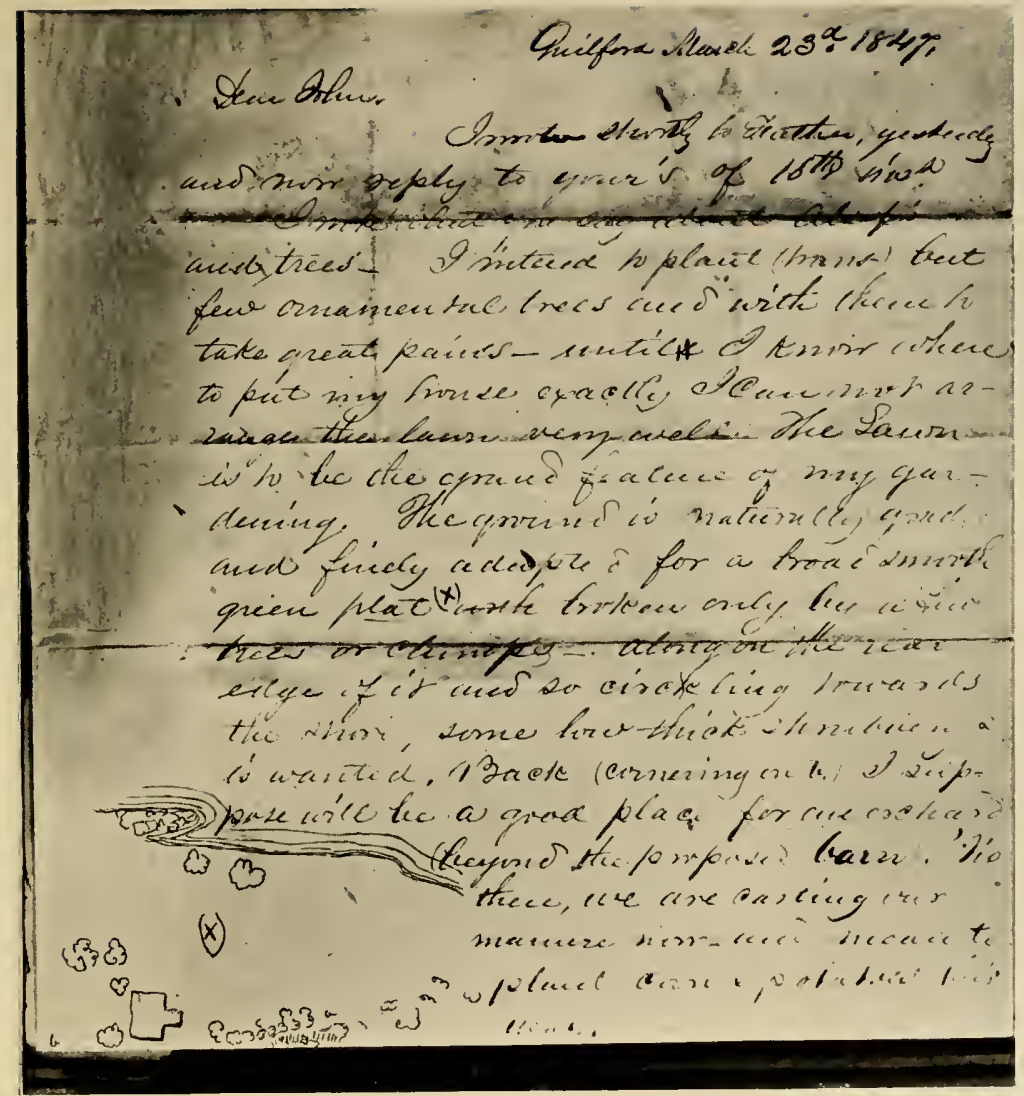

Facsimile of Letter with Mr. Olmsted's Earliest Sketch for Improvement of Grounds, 1847 



\section{Landscaping}

naturally graded and finely adapted for a broad, smooth green plat broken only by a few trees or clumps, along on the rear edge of it and so circling towards the shore, some low thick shrubbery (a) is wanted. Back (cornering on b) I suppose will be a good place for an orchard (beyond the proposed barn). 'Tis there we are carting our manure now and mean to plant corn and potatoes this year.

He consulted an architect regarding the proposed house, having himself first made sketches of floor plans and determined tentatively on a site. By November Io, I 847 he had planted trees, which he describes in a letter to his brother:

We have planted 75 apple trees in first rate manner, 60 quinces, too. About a dozen ornamental forest trees on the back bone of the point lot; which make quite a pretty show, -but I do not think many of them will live.

Further improvements were not carried out at Sachem's Head on account of the relinquishment of this farm for the larger and more promising place on Staten Island.

Mr. Frederick Kingsbury in I903, after Mr. Olmsted's death, recalled the development of the Staten Island farm and his friend's beginning as a landscape improver. When Mr. Kingsbury first visited the new farm, Mr. Olmsted explained how he intended to improve its appearance.

Mr. Kingsbury notes:

"The house was simple yet picturesque. It had been occupied by a tenant. The barns were quite near, and in the rear of the house was a small pond, fifteen or twenty feet in diameter, used for washing waggons, watering stock, and as a swimming place for dogs, ducks and geese. There was no turf near it. The whole place was as dirty and disorderly as the most bucolic person could desire. It was on the surroundings of the house that Olmsted first showed his genius in landscape construction.

"He moved the barns and all their belongings behind a knoll, he brought the road in so that it approached the house by a graceful curve, he turfed the borders of the pond and planted water plants on its edge and shielded it from all 
contamination. Thus, with a few strokes and at small expense he transformed the place from a very dirty, disagreeable farmyard to a gentleman's house. This was his first attempt at anything of the sort, and it was as successful as anything he ever did."

Mr. Kingsbury preserved a letter which his friend wrote him in the fall of 1848 , pursuing the subject of landscape surroundings:

I am glad you are disposed to notice such things as Harral's house so much. The effect such things have on the taste of a community,- and through that on their hearts and lives - the elevation,-I believe is very much underestimated.

I do exceedingly enjoy the view from my house, sometimes it is "wondrous beautiful"; just now for instance in this charming sleepy autumn haze, I cannot attempt to describe it, constantly changing, always renewedly interesting. I can tell you a few features always present. The water view extends over just half the circle. From the immediate opposite front, to the left of the arc, it is bounded by the horizon,-dark blue ocean, with forever distant sails coming up or sinking as they bid good-bye to America. Then all over that quarter at all distances are all sorts of vessels-at anchor or under sail-and in all variety constantly shifting. On the extreme right, across the water (Raritan Bay), the horizon is broken by the hills of Jersey some twelve miles off, I suppose. They sweep off gradually growing into something like mountains as they curve round facing us; yet to the front, suddenly and abruptly they end in a precipitous cliff similar to their relations, the Palisades of N. River. This is the Highland of Navesink, and we can just discern a cluster of white towers upon its brink, the fixed and revolving lights and the Telegraph Station.

A little beyond it (on the circle's edge) you imagine the horizon is half broken by a long yellowish white streak. It is the sand and spray or foam of Sandy Hook, and the three singularly distinct sails are nothing but its three white light- 


\section{Landscaping}

houses. There is yet another light in sight of us and in a dark night these six lights are curiously interesting,-affecting different minds with different ideas or feelings. To me they present a cheerful, neighborhood effect. To a stranger coming here in the dark it seems to me they must have a very sociable look. It is almost impossible to realize their distance. Staten Island I am sure you would like in itself,there are many charming inland views. 


\section{CHAPTER VI}

\section{RELATIONS WITH DOWNING}

SINCE Mr. Olmsted's particular interest in rural pursuits dated from 1844 and Andrew Jackson Downing did not meet his death until I 852 , one naturally looks for some connection between the two men. We know that Mr. Olmsted contributed to the Horticulturist, ${ }^{\text {I }}$ that he had letters of advice and introduction from Mr. Downing for his European trip of I850, and that he visited Downing at Newburgh, at least once. Nevertheless, there is surprisingly little to be found bearing definitely on their relations.

This subject was presented before the Boston Society of Landscape Architects in 1916, by Mr. John C. Olmsted, in a paper entitled "The Influence of A. J. Downing on the Designers of Central Park," from which the following is a brief selection.

"Those who knew A. J. Downing and have written about him have made it clear that he was just the sort of man to have had a marked influence on the young and impressionable men who later became the designers of Central Park. It is incontestable that he had every opportunity to impress his knowledge and cultivated taste in subjects related to park designing on at least the younger of those two young men, namely Calvert Vaux, because he had brought Mr. Vaux in the summer of 1850 from London, where he had been a pupil and draughtsman in the office of a London architect

I As early as Aug. 1847 (Vol. 2, No. 2) there appeared in the Horticulturist a letter from F. L. Olmsted, Sachem's Head, Guilford, Conn., dated June 29, I 847, under the heading "Queries on Sea-Coast Culture." The letter asked about quinces and protection of plants at the seashore. Two selections from the MS. of Walks and Talks were published in the Horticulturist (I85 I and I 852) with editorial endorsement by Mr. Downing, who reviewed the book at great length. An article on pears by F. L. Olmsted, Southside, Staten Island, appeared in the Horticulturist for Jan. I, 1852. 


\section{Relations with Downing}

named Truefitt, to act as his architectural assistant. He soon advanced him to be his partner. Mr. Downing was drowned about two years after he brought Mr. Vaux to this country. Mr. Vaux no doubt took over the business of the firm and completed the unfinished works. For that purpose I think he continued to live in Newburgh for probably two years or more, when he removed to New York City. . . .

"Knowing how wide awake and keen for intellectual cultivation and knowledge Mr. Calvert Vaux was, and having listened to innumerable conversations of his, I can imagine the profound influence upon the younger man of his intellectual intercourse with his well read and thoughtful partner, A. J. Downing. . . :

"The other designer of Central Park, Frederick Law Olmsted, it can well be imagined was somewhat influenced by A. J. Downing, although for the most part indirectly through the latter's writings. I know he several times spoke to me of A. J. Downing, but my recollection of what he said is too vague to be of much help. I simply have the impression that he had met and knew A. J. Downing both as a social acquaintance and as a man, like himself, professionally concerned in the education of the public in horticulture, agriculture and rural taste."

There is one letter preserved from Mr. Olmsted to $\mathrm{Mr}$. Downing, written after the former's return from abroad.

\section{SOUTHSIDE STATEN ISLAND,}

\section{DEAR SIR:}

Nov. 23, 1850.

I wish to thank you for your kindness in sending me, through Mr. Field last spring, a letter of introduction to Mr. Thompson of London. I did not arrive in London in season to attend the exhibition you wished me to, but I twice visited the gardens and enjoyed valuable conversations with $\mathrm{Mr}$. Thompson, who was very obliging and communicative. I took his advice as to what I should see in Paris, and I had thought to offer you some account of what most interested me there, but nearly all that was new and valuable of my observations there has already now appeared in the Horticulturist in the article by Mr. S. from the Journal of the London Soc'y. 
I spent only about one month on the Continent, mostly Germany, where I much enjoyed the social out-door life, and the frequent approaches to realizations of your ideal village. The custom of taking meals in the gardens or summer houses is very common; and it seemed to me the middle classes at least lived in the open air more than even the English; nor did it seem to me, as is frequently asserted, that their habits in these respects injured the family influence, or made Home any less homelike and lovable, but the contrary.

I saw the best parts of England, spending two months travelling through it on foot, seeing the country of course to great advantage, so that I feel as if I had not merely seen the rural character, but lived in it, and made it a part of me. I was then two months in Ireland and Scotland.

I wish you would when convenient do us (your disciples in Horticulture) the favor to explain distinctly the terms used to describe the different ways of growing pears, etc. I think your correspondents of the Horticulturist have generally used the term Standard to designate pears grown on pear stock only, and Dwarf for those on Quince or Thorn. But in Europe does not Dwarf mean a low ill-shapen tree, or a maiden tree that has lost its leader, and is only suitable for walls?... I was disappointed at not finding the pear grown on quince more abroad. Even at Paris I saw but few in open culture. Those at the Jardin des Plantes and at the Luxembourg are splendid full grown trees, and even this bad season were as full as could be desired of fruit. At Versailles they were mostly on trellis or walls- those en quenouille invariably looked unhealthy.

I saw your Fruits of America in France and England and Scotland; always shown as something for me to be proud of as your countryman.

Yours Respectfully,

Fred. Law Olmsted.

Mr. A. J. Downing. 


\section{Relations with Downing}

That the two men were regularly in correspondence on subjects of professional interest may be inferred from a bit in a letter to Charles Brace, not yet returned from the Continent, Jan. II, I85I: "I have written to Downing to tell him who you are. He wants me to write him in familiar letters Rough Impressions of Germany, etc. I find I cannot do it. I saw and know too little of Germany to write distinctly upon it, but I agree with him that whoever could do it would be in the way of doing a good deal of small good."

There is only a word to be found in the correspondence of that period about Mr. Olmsted's visit to Downing,-in a letter to Fred. Kingsbury, Aug. 5, I85I: "I liked Ossining and Newburgh. ${ }^{x}$ There is a piece in my book in one of the Horticulturists this summer, on Birkenhead Park mostly."

In an article by Mrs. Van Rensselaer in the Century for October, 1893, based directly on reminiscences which Mr. Olmsted gave her in conversation, it is stated that he visited Downing at Newburgh and made the acquaintance of Calvert Vaux.

The second volume ${ }^{2}$ of Mr. Olmsted's first book, Walks and Talks (1852), contained the following dedication:

To the Memory of Andrew Jackson Downing:

Whatever of good, true, and pleasant thought this volume may contain, is humbly and reverently inscribed.

Mr. Olmsted left among his papers a jotting evidently intended to be used in beginning an address for some occasion or other.

\section{A. J. Downing}

This is not a rhetorical introduction to my subject; it is a plain statement of one of the conclusions of a special study from which I have been led to regard Mr. Downing as a great

I Downing's home.

z The first had been dedicated to Mr. George Geddes, of "Fairmount." 
benefactor of our race and to desire almost above all things to do something to extend and prolong his influence. Although he had a philosophic turn of mind, I do not doubt that he builded better than he knew in that the plans and instructions which he gave to the public were far less excellent with reference to their ostensible ends, than they were with reference to the purpose of stimulating the exercise of judgment and taste in the audience addressed.

There are also a number of little sheets which Mr. Olmsted had had printed off, perhaps for the same occasion, and perhaps for some other public use, bearing the following quotation,-which expresses Mr. Olmsted's own ideals of democracy as well:

"And yet this broad ground of popular refinement must be taken in republican America, for it belongs of right more truly here than elsewhere. It is republican in its very idea and tendency. It takes up popular education where the common school and ballot-box leave it, and raises up the working man to the same level of enjoyment with the man of leisure and accomplishment. The higher social and artistic elements of every man's nature lie dormant within him, and every laborer is a possible gentleman, not by the possession of money or fine clothes, but through the refining influence of intellectual and moral culture. Open wide, therefore, the doors of your libraries and picture galleries, all ye true republicans! Build halls where knowledge shall be freely diffused among men, and not shut up within the narrow walls of narrower institutions. Plant spacious parks in your cities, and unloose their gates as wide as the gates of morning to the whole people. As there are no dark places at noon day, so education and culture-the true sunshine of the soul-will banish the plague spots of democracy; and the dread of the ignorant exclusive, who has no faith in the refinement of a republic, will stand abashed in the next century, before a whole people whose system of voluntary education embraces (combined with perfect individual freedom), not only common schools of rudimentary knowledge, but common enjoyments for all classes in the higher realms of art, letters, science, social recreations, and enjoyments. 


\section{Relations with Downing}

Were our legislators but wise enough to understand, today, the destinies of the New World, the gentility of Sir Philip Sidney, made universal, would be not half so much a miracle fifty years hence in America as the idea of a whole nation of laboring-men reading and writing, was, in his day, in England."

-A. J. Downing.

Mr. Olmsted and Mr. Vaux were consulted in I860 with regard to the memorial to Mr. Downing appropriately proposed to be erected in the Central Park but never carried out, and again in 1889 with reference to the Downing memorial park at Newburgh. Mrs. Downing, ${ }^{\mathbf{I}}$ who afterwards married Judge Monell, was a lifelong friend of the Vauxes and Olmsteds.

I In I867 Mrs. Downing, who had then become Mrs. Monell, wrote to Mr. Olmsted thanking him for "editing" Downing's Cottage Residences. The "editing" was probably limited to a friendly revision of proofs, since the posthumous editions of the book contain no references to Mr. Olmsted as editor. 


\section{CHAPTER VII}

\section{LANDSCAPE OBSERVATIONS FROM EUROPEAN TRAVEL}

WE know from Mr. Olmsted's own words that he had a particular interest in visiting parks both on his first European journey of 1850 , and in 1856 , when he was abroad attending to his publishing business and travelling also somewhat with his sisters. In his Walks and Talks of an American Farmer in England, first published in I852, there are a number of passages which should be quoted here, particularly as showing the trained observation of scenery which he later brought to his landscape designing, and his keen interest in the social and economic aspects of rural life. ${ }^{\mathrm{I}}$ It is interesting to know, too, that the book was illustrated by his own sketches. ${ }^{2}$

In regard to the preparations for his trip, Mr. Olmsted wrote in the Preface of his Walks and Talks: "With a hearty country appetite for narrative, I have spent, previous to my own journey, a great many long winter evenings in reading the books so frequently written by our literary tourists, upon England; and although I do not recollect one of them, the author of which was a farmer, or whose habits of life, professional interests, associations in society, and ordinary standards of comparison were not altogether different from my own, I remember none from which I did not derive entertainment and instruction."

LIST OF CUTS

DRAWN ON WOOD BY M. Field

From Sketches by the AUthor

I. The School-House (vignette, title page).

2. The English Coaster (calm).

3. The English Coaster (squalls).

4. The English Plough (vertical).

5. The English Plough (horizontal).

6. The Timber House (old farm-house).

7. Old English Domestic Architecture (Chester, 16th century).

8. Old English Domestic Architecture (Chester, I6th Century).

9. The Clod Crusher.

10. The Uley Cultivator.

I I. The Stage Wagon.

12. Old English Domestic Architecture (the village schoolmaster's cottage). 


\section{European Travel}

Although he went primarily as a farmer, he had in mind to see all sides of the country. He wrote to his father before sailing: "I can have now the advantage of letters.from Norton to the Scotch farmers, from Field to the English, from Antisell to the Irish. They all have warm friends there yet among just the men I want to learn from. Parsons will introduce me to the gardens and nurseries. Prof. Johnston returns to Edinboro, Judge Emerson and Stevens direct me to the lions of London, and Field opens the manufacturies."

\section{BIRKENHEAD AND ITS PARK}

BIRKENHEAD is the most important suburb of Liverpool, having the same relation to it that Charlestown has to Boston or Brooklyn to New York. When the first line of Liverpool packets was established, there were not half a dozen houses here; it now has a population of many thousands, and is increasing with a rapidity hardly paralleled in the New World. This is greatly owing to the very liberal and enterprising policy of the land-owners, which affords an example that might be profitably followed in the vicinity of many of our own large towns. There are several public squares, and the streets and places are broad, and well paved and lighted. A considerable part of the town has been built with reference to general effect, from the plans and under the direction of a talented architect, Gillespie Graham. . . .

The baker had begged of us not to leave Birkenhead without seeing their new park, and at his suggestion we left our knapsacks with him, and proceeded to it. As we approached the entrance, we were met by women and girls, who, holding out a cup of milk, asked us-"Will you take a cup of milk, sirs? - good, cool, sweet, cow's milk, gentlemen, or right warm from the ass!" And at the gate was a herd of donkeys, some with cans of milk strapped to them, others saddled and bridled, to be let for ladies and children to ride.

The gateway, which is about a mile and a half from the ferry, and quite back of the town, is a great, massive block of handsome Ionic architecture, standing alone, and unsup- 
ported by any thing else in the vicinity, and looking, as I think, heavy and awkward. There is a sort of grandeur about it that the English are fond of, but which, when it is entirely separate from all other architectural constructions, always strikes me unpleasantly. It seems intended as an impressive preface to a great display of art within; but here, as well as at Eaton Park, and other places I have since seen, it is not followed up with great things, the grounds immediately within the grand entrance being very simple, and apparently rather overlooked by the gardener. There is a large archway for carriages, and two smaller ones for those on foot, and, on either side, and over these, are rooms, which probably serve as inconvenient lodges for the labourers. No porter appears, and the gates are freely open to the public.

Walking a short distance up an avenue, we passed through another light iron gate into a thick, luxuriant and diversified garden. Five minutes of admiration, and a few more spent in studying the manner in which art had been employed to obtain from nature so much beauty, and I was ready to admit that in democratic America there was nothing to be thought of as comparable with this People's Garden. Indeed, gardening had here reached a perfection that I had never before dreamed of. I cannot undertake to describe the effect of so much taste and skill as had evidently been employed; I will only tell you, that we passed by winding paths over acres and acres, with a constant varying surface, where on all sides were growing every variety of shrubs and flowers, with more than natural grace, all set in borders of greenest, closest turf, and all kept with most consummate neatness. At a distance of a quarter of a mile from the gate, we came to an open field of clean, bright green-sward, closely mown, on which a large tent was pitched, and a party of boys in one part, and a party of gentlemen in another, were playing cricket. Beyond this was a large meadow with rich groups of trees, under which a flock of sheep were reposing, 


\section{European Travel}

and girls and women with children, were playing. While watching the cricketers, we were threatened with a shower, and hastened back to look for shelter, which we found in a pagoda, on an island approached by a Chinese bridge. It was soon filled, as were the other ornamental buildings, by a crowd of those who, like ourselves, had been overtaken in the grounds by the rain; and I was glad to observe that the privileges of the garden were enjoyed about equally by all classes. There were some who were attended by servants, and sent at once for their carriages, but a large proportion were of the common ranks, and a few women with children, or suffering from ill health, were evidently the wives of very humble labourers. There were a number of strangers, and some we observed with notebooks and portfolios, that seemed to have come from a distance to study from the garden. The summer-houses, lodges, bridges, etc., were all well constructed, and of undecaying materials. One of the bridges which we crossed was of our countryman Remington's patent, an extremely light and graceful erection.

I obtained most of the following information from the head working-gardener.

The site of the park and garden was, ten years ago, a flat, sterile clay farm. It was placed in the hands of Mr. Paxton, in June, 1844 , by whom it was laid out in its present form by June of the following year. Carriage roads, thirtyfour feet wide, with borders of ten feet, and walks varying in width, were first drawn and made. The excavation for a pond was also made, and the earth obtained from these sources used for making mounds and to vary the surface, which has been done with much naturalness and taste. The whole ground was thoroughly under-drained, the minor drains of stone, the main, of tile. By these sufficient water is obtained to fully supply the pond, or lake, as they call it, which is from twenty to forty feet wide, and about three feet deep, and meanders for a long distance through the garden. It is stocked with aquatic plants, gold fish and swans. 
The roads are macadamized. On each side of the carriage way, and of all the walks, pipes for drainage are laid, which communicate with deep main drains that run under the edge of all the mounds or flower beds. The walks are laid first with six inches of fine broken stone, then three inches cinders, and the surface with six inches of fine rolled gravel. All the stones on the ground which were not used for these purposes, were laid in masses of rock-work, and mosses and rock-plants attached to them. The mounds were then planted with shrubs, and heaths and ferns, and the beds with flowering plants. Between these, and the walks and drives, is everywhere a belt of turf (which, by the way, is kept close cut with short, broad scythes, and shears, and swept with hair-brooms, as we saw). Then the rural lodges, temple, pavilion, bridges, orchestra for a band of instrumental music, etc., were built. And so, in one year, the skeleton of this delightful garden was complete.

But this is but a small part. Besides the cricket and an archery ground, large valleys were made verdant, extensive drives arranged, plantations, clumps, and avenues of trees formed, and a large park laid out. And all this magnificent pleasure-ground is entirely, unreservedly, and for ever the people's own. The poorest British peasant is as free to enjoy it in all its parts as the British queen. More than that, the baker of Birkenhead has the pride of an OwNER in it.

Is it not a grand good thing? But you are inquiring who paid for it. The honest owners- the most wise and worthy townspeople of Birkenhead-in the same way that the New Yorkers pay for "the Tombs" and the Hospital, and the cleaning (as they amusingly say) of their streets.

Of the farm which was purchased, one hundred and twenty acres have been disposed of in the way I have described. The remaining sixty acres, encircling the park and garden, were reserved to be sold or rented, after being well graded, streeted, and planted, for private building lots. Several fine mansions are already built on these (having 


\section{European Travel}

private entrances to the park), and the rest now sell at $\$$ I.25 a square yard. The whole concern cost the town between five and six hundred thousand dollars. It gives employment, at present, to ten gardeners and labourers in summer, and to five in winter.

The generous spirit and fearless enterprise that has accomplished this, has not been otherwise forgetful of the health and comfort of the poor. Among other things, I remember, a public washing and bathing house for the town is provided. I should have mentioned also, in connection with the market, that in the outskirts of the town there is a range of stone slaughter-houses, with stables, yards, pens, supplies of hot and cold water and other arrangements and conveniences, that enlightened regard for health and decency would suggest.

The consequence of all these sorts of things is, that all about the town lands, which a few years ago were almost worthless wastes, have become of priceless value; where no sound was heard but the bleating of goats and braying of asses complaining of their pasturage, there is now the hasty click and clatter of many hundred busy trowels and hammers. You may drive through wide and thronged streets of stately edifices, where were only a few scattered huts, surrounded by quagmires. Docks of unequalled size and grandeur are building, and a forest of masts grows along the shore; and there is no doubt that this young town is to be not only remarkable as a most agreeable and healthy place of residence, but that it will soon be distinguished for extensive and profitable commerce. It seems to me to be the only town I ever saw that has been really built at all in accordance with the advanced science, taste and enterprising spirit that are supposed to distinguish the nineteenth century. I do not doubt it might be found to have plenty of exceptions to its general character, but I did not inquire for these, nor did I happen to observe them. Certainly, in what I have noticed, it is a model town, and may be held up as an example 
not only to philanthropists and men of taste, but to speculators and men of business.

After leaving the park, we ascended a hill, from the top of which we had a fine view of Liverpool and Birkenhead. Its sides were covered with villas, with little gardens about them. The architecture was generally less fantastic, and the style and materials of building more substantial than is usually employed in the same class of residences with us. Yet there was a good deal of the same stuck up and uneasy pretentious air about them that the suburban houses of our own city people so commonly have. Possibly this is the effect of association, in my mind, of steady, reliable worth and friendship with plain or old-fashioned dwellings, for I often find it difficult to discover in the buildings themselves the element of such expression. I am inclined to think it is more generally owing to some disunity in the design,- - often, perhaps, to a want of keeping between the mansion and its grounds or its situation. The architect and the gardener do not understand each other, and commonly the owner or resident is totally at variance in his tastes and intentions from both; or the man whose ideas the plan is made to serve, or who pays for it, has no true independent taste, but had fancies to be accommodated, which only follow confusedly after custom or fashion. I think, with Ruskin, it is a pity that every man's house cannot be really his own, and that he can not make all that is true, beautiful, and good in his own character, tastes, pursuits, and history manifest in it.

But however fanciful and uncomfortable many of the villa houses about Liverpool and Birkenhead appear at first sight, the substantial and thorough manner in which most of them are built will atone for many faults. The friendship of nature has been secured to them. Dampness, heat, cold, will be welcome to do their best. Every day they will improve. In fifty or a hundred years fashions may change, and they will appear, perhaps, quaint, possibly grotesque; but still strong, home-like, and hospitable. They have no 


\section{European Travel}

shingles to rot, no glued and puttied and painted gimcrackery to warp and crack and moulder; and can never look so shabby, and desolate, and dreary, as will nine-tenths of the buildings of the same denomination now erecting about New York, almost as soon as they lose the raw, cheerless, imposter-like airs which seem almost inseparable from their newness.

\section{A FERME ORNÉE}

A few miles further on we came to a large, park-like pasture, bounded by a neatly trimmed hedge, and entered by a simple gate, from which a private road ran curving among a few clumps of trees to a mansion about a furlong distant. We entered, and rested ourselves awhile at the foot of some large oaks. The house was nearly hidden among trees, and these, seen across the clear grass land, were the finest groups of foliage we had ever seen. A peculiar character was given it by one or two copper-leaved beeches-large, tall trees, thickly branched from the very surface of the ground. (These trees, which are frequently used with great good effect in landscape gardening in England, are rare in America, though they may be had at the nurseries. There are two sorts, one much less red than the other.) The cattle in this pasture-lawn were small and black, brisk and wildlooking, but so tame in reality, that as we lay under the tree, they came up and licked our hands like dogs. The whole picture completely realized Willis's beautiful ideal, "The Cottage Insoucieuse."

\section{EATON PARK}

In the afternoon we walked to Eaton Park.

Probably there is no object of art that Americans of cultivated taste generally more long to see in Europe than 
an English park. What artist so noble, has often been my thought, as he who, with far-reaching conception of beauty and designing power, sketches the outline, writes the colours, and directs the shadows of a picture so great that Nature shall be employed upon it for generations, before the work he has arranged for her shall realize his intentions. ${ }^{\mathrm{I}}$

We came to the great castellated edifice that I have before spoken of as the gateway to the park. Such we were told it was, and were therefore surprised to find within only a long, straight road, with but tolerable mowing lots alternating by the side of it, with thick plantations of trees, no way differing from the twenty-year old natural wood of my own farm, except that hollies, laurels, and our common dogwood were planted regularly along the edge.

We tramped on for several miles through this tame scenery and most ungentlemanly farming, until it became really tiresome. At length the wood fell back, and the road was lined for some way with a double row of fine elms. Still no deer. A little further, and we came to a cottage most beautifully draped with ivy; passed through another gate. Ah! here is the real park at last.

A gracefully, irregular, gently undulating surface of closecropped pasture land, reaching way off illimitably; dark green in colour; very old, but not very large trees scattered singly and in groups - so far apart as to throw long unbroken shadows across broad openings of light, and leave the view in several directions unobstructed for a long distance. Herds of fallow-deer, fawns, cattle, sheep and lambs quietly feeding near us, and moving slowly in masses at a distance; a warm atmosphere, descending sun, and sublime shadows from fleecy clouds transiently darkening in succession, sunny surface, cool woodside, flocks and herds, and foliage.

I Mr. Olmsted was fond of quoting this passage in his later professional writing. 


\section{European Travel}

The road ran on winding through this. We drew a long breath, and walked slowly for a little way, then turned aside at the nearest tree, and lay down to take it all in satisfactorily.

We concluded that the sheep and cattle were of the most value for their effect in the landscape; but it was a little exciting to us to watch the deer, particularly as we would sometimes see them in a large herd leisurely moving across an opening among the trees, a long way off, and barely distinguishable.

It is not my business to attempt a criticism of "the finest specimen of the pointed Gothic" in England; but I may honestly say that it did not, as a whole, produce the expected effect of grandeur or sublimity upon us, without trying to find reasons for the failure. Even when we came to look at it closely, we found little to admire. There was no great simple beauty in it as a mass, nor yet vigorous original character enough in the details to make them an interesting study. The edifice is long and low, and covered with an immense amount of meaningless decoration.

Such was our first impression, and we were greatly disappointed, you may be sure. We admired it more afterwards on the other side, from the middle of a great garden, where it seems to stand much higher, being set up on terraces, and gaining much, I suspect, from the extension of architectural character to the grounds in its front. Here we acknowledged a good deal of magnificence in its effect. Still it seemed as if it might have been obtained in some other style, with less labour, and was much frittered away in the confusion of ornament.

This garden is a curiosity. It is in the geometrical style, and covers eight acres, it is said, though it does not seem nearly that to the eye. It is merely a succession of small arabesque figures of fine grass or flower beds, set in hard, 


\section{Frederick Law Olmsted}

rolled, dark-coloured gravel. The surface, dropping by long terraces from the steps of the hall to the river, is otherwise only varied by stiff pyramidal yews and box, and a few vases. On the whole, the effect of it in connection with the house, and looking towards it, is good, more so than I should have expected; and it falls so rapidly, that it affects the landscape seen in this distance from the house but very little. This is exquisitely beautiful, looking across the Dee, over a lovely valley towards some high, blue mountains. From other parts of the hall grand vistas open through long avenues of elms, and there are some noble single trees about the lawn.

This English elm is a much finer tree than $I$ had been aware of-very tall, yet with drooping limbs and fine thick foliage; not nearly as fine as a single tree as our elm, but even more effective, I think, in masses, because thicker and better filled out in its general outline.

\section{ENGLISH LANDSCAPE}

I must say, that on the whole, the agriculture of Cheshire, as the first sample of that of England which is presented to me, is far below my expectations. There are sufficient reasons to expect that we shall find other parts much superior to it; but what we have seen quite disposes of the common picture which our railroad and stage-coach travellers are in the habit of giving to our imagination, by saying that "all England is like a garden." Meaning only a "landscape garden," a beautiful and harmonious combination of hill and dale, with the richest masses of trees, and groups and lines of shrubbery, the greenest turf and most picturesque buildings, it might be appropriately said of many parts, particularly in the south of the country. But, with reference to cultivation, and the productiveness of the land, it might be quite as truly applied to some small districts of our own country as to this part of England. 


\section{European Travel}

We reach another lane and cultivated fields again, and, being on elevated ground at the knarly feet of a glorious, breezy, gray, old beech-tree, lay ourselves down, and, looking back upon the extensive landscape, tell our friend in what it differs from American scenery.

The great beauty and peculiarity of the English landscape is to be found in the frequent long, graceful lines of deep green hedges and hedge-row timber, crossing hill, valley, and plain, in every direction; and in the occasional large trees, dotting the broad fields, either singly or in small groups, left to their natural open growth, (for ship-timber, and, while they stand, for cattle shades,) therefore branching low and spreading wide, and more beautiful, much more beautiful, than we often allow our trees to make themselves. The less frequent brilliancy of broad streams or ponds of water, also distinguishes the prospect from those we are accustomed to, though there are often small brooks or pools, and much marshy land, and England may be called a wellwatered country. In the foreground you will notice the quaint buildings, generally pleasing objects in themselves, often supporting what is most agreeable of all, and what you can never fail to admire, never see any thing ugly or homely under, a curtain of ivy or other creepers; the ditches and the banks by their side, on which the hedges are planted; the clean and careful cultivation, and general tidiness of the agriculture; and the deep, narrow, crooked, gulch-like lane, or the smooth, clean, matchless, broad highway. Where trees are set in masses for ornament, the Norway spruce and the red beech generally give a dark, ponderous tone, which we seldom see in America; and in a hilly and unfertile country there are usually extensive patches of the larch, having a brown hue. The English elm is the most common tree in small parks or about country-houses. It appears, at a little distance, more like our hickory, when the latter grows upon a rich soil, and is not cramped, as sometimes in our river intervals, than any other American tree. 
There seems to me to be a certain peculiarity in English foliage, which I can but little more than allude to, not having the skill to describe. You seem to see each particular leaf, (instead of a confused leafiness,) more than in our trees; or it is as if the face of each leaf was parallel, and more equally lighted than in our foliage. It is perhaps only owing to a greater density, and better filling up, and more even growth of the outer twigs of the trees, than is common in our drier climate. I think that our maple woods have more resemblance to it than others.

There is usually a much milder light over an English landscape than an American, and the distance and shady parts are more indistinct. It is rare that there is not a haziness, slightly like that of our Indian summer in the atmosphere, and the colours of every thing, except of the foliage are less brilliant and vivacious than we are accustomed to. The sublime or the picturesque in nature is much more rare in England, except on the sea-coast, than in America; but there is every where a great deal of quiet, peaceful, graceful beauty, which the works of man have generally added to, and which I remember but little at home that will compare with. This Herefordshire reminds me of the valley in Connecticut, between Middletown and Springfield. The valley of the Mohawk and the upper part of the Hudson, is also in some parts English-like.

Soon after leaving Warminster, began a very different style of landscape from what I have before seen: long ranges and large groups of high hills with gentle and gracefully undulating slopes; broad and deep cells between and within them, through which flow in tortuous channels streamlets of exceedingly pure, sparkling water. These hills are bare of trees, except rarely a close body of them, covering a space of perhaps an acre, and evidently planted by man. Within the shelter of these you will sometimes 


\section{European Travel}

see that there is a large farm-house with a small range of stables. The valleys are cultivated, but the hills in greater part are covered, without the slightest variety, except what arises from the changing contour of the ground, with short, wiry grass, standing thinly, but sufficiently close to give the appearance at a little distance from the eye, of a smooth, velvety, green surface. Among the first of the hills I observed, at a high elevation, long angular ramparts and earthworks, all greened over. Within them at the summit of the hill were several extensive tumuli, evidently artificial, (though I find nothing about it in the books,) and on the top of one of these was a shepherd and dog and a large flock of sheep, clear and coldly distinct, and appearing of gigantic size against the leaden clouds behind. In the course of the day I met with many of these flocks, and nearly all of the hill-land seemed given up to them. I was upon the border, in fact, of the great Southdown district, and, during the next week, the greater part of the country through which we were travelling, was of the same general character of landscape, though frequently not as green, varied, and pleasing as in these outskirts of it.

\section{THE DESCRIPTION OF SCENERY}

There is always a strong temptation upon the traveller to endeavor to so describe fine scenery, and the feelings which it has occasioned him, that they may be reproduced to the imagination of his friends. Judging from my own experience, this purpose always fails. I have never yet seen any thing celebrated in scenery, of which I had previously obtained a correct conception. Certain striking, prominent points, that the power of language has been most directed to the painting of, almost invariably disappoint, and seem little and commonplace, after the exaggerated forms which have been brought before the mind's eye. Beauty, grandeur, 
impressiveness, in any way, from scenery, is not often to be found in a few prominent, distinguishable features, but in the manner and the unobserved materials with which these are connected and combined. Clouds, lights, states of the atmosphere, and circumstances that we cannot always detect, affect all landscapes, and especially landscapes in which the vicinity of a body of water is an element, much more than we are often aware. So it is that the impatient first glance of the young traveller, or the impertinent critical stare of the old tourist, is almost never satisfied, if the honest truth be admitted, in what it has been led to previously imagine. I have heard "Niagara is a mill-dam," "Rome is a humbug."

The deep sentiments of nature that we sometimes seem to have been made the confidant of, when among the mountains, or on the moors or the ocean,-even those of man wrought out in architecture and sculpture and painting, or of man working in unison with Nature, as sometimes in the English parks, on the Rhine, and here on the Isle of Wight,- - such revealings are beyond words; they never could be transcribed into note-books and diaries, and so descriptions of them become caricatures, and when we see them, we at first say we are disappointed that we find not the monsters we were told of.

Dame Nature is a gentlewoman. No guide's fee will obtain you her favour, no abrupt demand; hardly will she bear questioning, or direct, curious gazing at her beauty; least of all, will she reveal it truly to the hurried glance of the passing traveller, while he waits for his dinner, or fresh horses, or fuel and water; always we must quietly and unimpatiently wait upon it. Gradually and silently the charm comes over us; the beauty has entered our souls; we know not exactly when or how, but going away we remember it with a tender, subdued, filial-like joy.

Does this seem nonsense to you? Very likely, for I am talking of what I don't understand. Nature treats me so 


\section{European Travel}

strangely; it's past my speaking sensibly of, and yet, as a part of my travelling experience, I would speak of it. At times I seem myself to be her favourite, and she brings me to my knees in deep feeling, such as she blesses no other with; oftener I see others in ecstasies, while I am left to sentimentalize and mourn, or to be critical, and sneering, and infidel. Nonsense still; but tell me, do you think it is only for greed of trouts that your great and sensitive man lingers long, intently stooping over dark pools in the spray of the mountain torrents, or stealing softly a way through the bending rushes, or kneeling lowly on the darkest verdure of the shaded meadow? What else? I know not what he thinks, but of this I am assured: while his mind is most intent upon his trivial sport, his heart and soul will be far more absorbent of the rugged strength, the diffuse, impetuous brilliance, the indefinite gliding grace, or the peaceful twilight loveliness, of the scenes around him, than if he went out searching, labouring directly for it as for bread and fame.

The greater part of the Isle of Wight is more dreary, desolate, bare, and monotonous than any equal extent of land you probably ever saw in America-would be, rather, if it were not that you are rarely out of sight of the sea; and no landscape, of which that is a part, ever can be without variety and ever-changing interest. It is, in fact down-land in the interior, exactly like that I described in Wiltshire, and sometimes breaking down into such bright dells as I there told of. But on the south shore it is rocky, craggy; and after you have walked through a rather dull country, though pleasing on the whole, for hours after landing, you come gradually to where the majesty of vastness, peculiar to the downs and the ocean, alternates or mingles with dark, picturesque, rugged ravines, chasms, and water-gaps, sublime rock-masses, and soft, warm smiling inviting dells and dingles; and, withal, there is a strange and fascinating enrichment of half-tropical foliage, so deep, graceful, and luxuriant, as I never saw before any where in the world. All this district is thickly 
inhabited, and yet so well covered with verdure, or often so tastefully appropriate-quiet, cosy, ungenteel, yet elegantare the cottages, that they often add to, rather than insult and destroy, the natural charm of their neighbourhood. I am sorry to say, that among the later erections there are a number of very strong exceptions to this remark.

As to Mr. Olmsted's travels in I856, we have a memorandum that he visited Rome, Genoa, Florence, Prague, Leipzig, and Dresden as well as London. We have a delightful reference to his brief Italian visit in a letter written to Charles Eliot, then abroad, March 4, I886:

I think that you want to get hints for gardening in dry, hot regions of our country from Italy, Spain and south of France. You do not, it seems to me, get much of value from the show villas to which you go as a matter of course. But I remember modester places which struck me as delightful, and one or two that I cannot now specify I made my way into and faintly recall always when I think of what should be done in California, Colorado, New Mexico, or really in Georgia and Florida. I speak of a month in all Italy more than thirty years ago when I had no more thought of being a landscape architect than of being a Cardinal. Yet my experience has been of much value to me. 


\section{CHAPTER VIII}

\section{SOUTHERN TRIPS, I $852-1854$}

From the letters and books relating to his Southern journeys, there is less of scenery or of rural art. He was concerned with giving a true picture of the economic and social conditions in the South, especially as affected by slavery, and his observations were directed mainly to men and their affairs rather than to their landscape surroundings. There are, however, numerous passages of great interest in this regard, especially on the Texas journey of $1853-4$. Several are here given.

One is written from San Antonio, Texas, March 12, I854, to a friend.

Meantime we are traveling about, without definite aim, in an orignial but, on the whole, very pleasant fashion. The spring here is very beautiful, the prairies are not mere seas of coarse grass, but one of varied surface, with thick wooded borders and many trees and shrubs, standing singly and in small islands. Having been generally burnt over or the rank grass fed closely down, they have very frequently a fine close lawn-like turf, making an extremely rich landscape. At this season, moreover, there are a very great variety of pretty, small, modest flowers, such as I send you, growing often very thickly in the grass. There is an evergreen shrub rare, and new to me, which is the finest shrub I have ever seen. ${ }^{x}$ Its leaves are Acacia-like but evergreen, bright and glossy like Laurel, and it bears a cluster like those

This plant has been identified by the Botanist of the U. S. Bureau of Plant Industries as that commonly called Frijolito or Frijolillo (Sophora secundiflora). 
of the Horsechestnut, of deep blue and lilac bloom, with a perfume like that of grapes.

\section{THE WESTERN PRAIRIES}

The impression as we emerged, strengthened by a warm, calm atmosphere, was very charming. The live-oaks, standing alone or in picturesque groups near and far upon the clean sward, which rolled in long waves that took, on their various slopes, bright light or half shadows from the afternoon sun, contributed mainly to an effect which was very new and striking, though still natural, like a happy new melody. We stopped, and, from the trunk of a superb old tree, preserved a sketched outline of its low gnarled limbs, and of the scene beyond them.

Had we known that this was the first one of a thousand similar scenes, that were now to charm us day after day, we should have, perhaps, spared ourselves the pains. We were, in fact just entering a vast region of which live-oak prairies are the characteristic. It extends throughout the greater part of Western Texas, as far as the small streams near San Antonio, beyond which the dwarf mesquit and its congeners are found. The live-oak is almost the only tree away from the river bottoms, and everywhere gives the marked features to the landscape.

The live-oaks are often short, and even stunted in growth, lacking the rich vigor and full foliage of those further east. Occasionally, a tree is met with, which has escaped its share of injury from prairie burnings and northers, and has grown into a symmetrical and glorious beauty. But such are comparatively rare. Most of them are meagerly furnished with leaves, and as the leaf, in shape, size, and hue, has a general similarity to that of the olive, the distant effect is strikingly similar. As far West as beyond the Guadalupe, they are thickly hung with the gray Spanish moss, whose weird color, and slow, pendulous motions, harmonize pecu- 


\section{Southern Trips}

liarly with the tone of the tree itself, especially where, upon the round, rocky, mountain ledges, its distorted roots cling, disputing a scant nourishment with the stunted grass.

\section{SAN ANTONIO}

We have no city, except, perhaps, New Orleans, that can vie, in point of the picturesque interest that attaches to odd and antiquated foreignness, with San Antonio. Its jumble of races, costumes, languages and buildings; its religious ruins, holding to an antiquity, for us, indistinct enough to breed an unaccustomed solemnity; its remote, isolated, outposted situation, and the vague conviction that it is the first of a new class of conquered cities into whose decaying streets our rattling life is to be infused, combine with the heroic touches in its history to enliven and satisfy your traveller's curiosity.

.. . [The streets] are laid out with tolerable regularity, parallel with the sides of the main plaza, and are pretty distinctly shared among the nations that use them.

In the outskirts of the town are many good residences, recently erected by Americans. They are mostly of the creamy limestone, which is found in abundance near by. It is of a very agreeable shade, readily sawed and cut, suffciently durable, and can be procured at a moderate cost. When the grounds around them shall have been put in correspondence with the style of these houses, they will make enviable homes.

\section{THE SAN ANTONIO SPRING}

There are, besides the missions, several pleasant points for excursions in the neighborhood, particularly those to the 
San Antonio and San Pedro Springs. The latter is a wooded spot of great beauty, but a mile or two from the town, and boasts a restaurant and beer-garden beyond its natural attractions. The San Antonio Spring may be classed as of the first water among the gems of the natural world. The whole river gushes up in one sparkling burst from the earth. It has all the beautiful accompaniments of a smaller spring, moss, pebbles, seclusion, sparkling sunbeams and dense overhanging luxuriant foliage. The effect is overpowering. It is beyond your possible conceptions of a spring.

\section{SEGUIN}

About a mile from the river we entered Seguin. It is the prettiest town in Texas; at least of those we saw. It stands on elevated ground, in a grove of shaggy live-oaks, which have been left untouched, in their natural number and position, the streets straying through them in convenient directions, not always at right angles.

The following selections are from the Back Country book:

\section{THE LANDSCAPE-ROSE HEDGES}

For some miles about St. Francisville the landscape has an open, suburban character, with residences indicative of rapidly accumulating wealth, and advancement in luxury among the proprietors. For twenty miles to the north of the town, there is on both sides a succession of large sugar and cotton plantations. Much land still remains uncultivated, however. The roadside fences are generally hedges of roses-Cherokee and sweetbrier. These are planted first by the side of a common rail fence, which, while they are young, supports them in the manner of a trellis; as they 


\section{Southern Trips}

grow older they fall each way, and mat together, finally forming a confused, sprawling, slovenly thicket, often ten feet in breadth and four to six feet high. Trumpet creepers, grape-vines, green-briers, and in very rich soil, cane, grow up through the mat of roses, and add to its strength. It is not as pretty as a trimmer hedge, yet very agreeable, and the road being sometimes narrow, deep, and lane like, delightful memories of England were often brought to mind.

\section{THE BLUFF}

. . The grand feature of Natchez is the bluff, terminating in an abrupt precipice over the river, with the public garden upon it. Of this I never had heard, and when, after seeing my horse dried off and eating his oats with great satisfaction,-- the first time he has ever tasted oats, I suppose,-I strolled off to see the town, I came upon it by surprise. I entered a gate and walked up a slope, supposing that I was approaching the ridge or summit of a hill, and expecting to see beyond it a corresponding slope and the town again, continuing in terraced streets to the river. I found myself, almost at the moment I discovered that it was not so, on the very edge of a stupendous cliff, and before me an indescribably vast expanse of forest, extending on every hand to a hazy horizon, in which, directly in front of me, swung the round, red, setting sun.

Through the otherwise unbroken forest, the Mississippi had opened a passage for itself, forming a perfect arc, the hither shore of the middle of the curve being hidden under the crest of the cliff, and the two ends lost in the vast obscurity of the Great West. Overlooked from such an eminence, the size of the Mississippi can be realized,-a thing difficult under ordinary circumstances; but though the fret of a swelling torrent is not wanting, it is perceptible only as the most delicate chasing upon the broad, gleaming ex- 
panse of polished steel, which at once shamed all my previous conceptions of the appearance of the greatest of rivers. Coming closer to the edge and looking downward, you see the lower town, its roofs with water flowing all around them, and its pigmy people wading, and laboring to carry upward their goods and furniture, in danger from a rising movement of the great water. Poor people, emigrants and niggers only.

I lay down, and would have reposed my mind in the infinite vision westward, but was presently disturbed by a hog which came grunting near me, rooting in the poor turf of this wonderful garden. I rose and walked its length. Little more has been done than to inclose a space along the edge, which would have been dangerous to build upon, to cut out some curving alleys now recaptured by the grass and weeds, and to plant a few succulent trees. A road to the lower town, cutting through it, is crossed by slight wooden footbridges, and there are some rough plank benches-adorned with stenciled "medical" advertisements. Some shrubs are planted on the crumbling face of the cliff, so near the top that the swine can obtain access to them. A man, bearded and smoking, and a woman with him, sitting at the extreme end, were the only visitors except myself and the swine. 


\section{CHAPTER IX}

\section{REPUTATION IN I857}

Although in his Walks and Talks the public had ample evidence of $\mathrm{Mr}$. Olmsted's taste in scenery, he was known principally as a literary man, a writer on agriculture, and a student of our social and economic conditions. His reasoned observations had been widely circulated through his letters in the New York Times and the books subsequently made up from these, ${ }^{\mathrm{I}}$ which are still considered to give the truest picture of the South before the war. Mr. Raymond of the Times is quoted in I 854 as thinking "highly of his powers of observation and detailed reporting, giving just the facts that people want."

Among his intimates he was known as an enthusiast and keen analyst in debate. It is pleasant to quote two references to these qualities in letters, which were prophetic, in spirit if not in exact detail:

Boston, May 8, I847.

(From F. J. Kingsbury to J. H. Olmsted.)

"It is pretty much all true what you say about Fred. But living and growing and experience will have to answer for him instead of college discipline. He is an enthusiast by nature though, and all the Greek and Latin in the world wouldn't have driven that out of him. Well the world needs such men, and one thing is curious, disappointments never seem to trouble them. They must in the nature of things meet with them often and yet they go right on in the same old way just as if it had not happened. They never get disheartened. I think Fred will be one of that sort. Many of his favorite schemes will go to naught but he'll throw it aside and try another and spoil that and forget them

- Seaboard Slave States, Journey in Texas, and Back Country. 
both while you or I might have been blubbering over the ruins of the first."

And in the Life and Letters of Charles Loring Brace, ${ }^{\mathrm{I}}$ there is a letter probably late in 1848 :

"I must say Fred is getting to argue with the utmost keenness,- - a regular Dr. Taylor mind in its analytic power! But what is queerest, never able to exercise that power except in discussion! $\mathrm{He}$ is another Taylorite in his virtue theory. I shouldn't be surprised if he turned out something rather remarkable among men yet. . . .'

Although he had not had a chance to prove his executive ability in any public capacity, he was known as a capable manager in the handling of farm labor. Very early in his agricultural career, there is an evidence of this in a letter (I848) to his brother:

I finally got things fixed so I could leave without much anxiety. Robert returned, pretty well recovered; and work cut out, with written directions, for every man of such sort that they will be profitably and seasonably employed 'til I return, without much need of judgment.

His democratic ideals in general were well understood from his writings. There are some passages from letters written early in his career as a landscape architect which further interpret these with special regard to his chosen profession.

The letter of 1860 , addressed to a subordinate who had referred to the difference in their "stations in life," contains the following:

The phrase "stations in life" is ordinarily used with a meaning the propriety of which I am not accustomed to recognize. That $I$ have enjoyed greater advantages of education in some respects than most of the keepers is true, but so far as this means book-education, there is no man among you who has it not in his power to obtain a better education than mine, during the ordinary period of reserve duty, within a very few years. As for my education in other

' Published I894, p. 61-62. 


\section{Reputation in 1857}

respects, I mean in those respects which if anything entitle me to my present position, I have obtained it by reason of no advantages which many of you might not have had. The best of my travelling has been done on foot at a cost of 70 cents a day, or working my passage as a common seaman. My practical horticultural education, I mean that not gained by reading, was in part acquired while engaged as a laborer, looking to working men as my masters and teachers. It is then impossible for me to have any hearty or habitual respect for the superiority of one man over another in station in life except as superiority of station means higher responsibility and larger duty.

In I863, when the political situation on the Central Park made it difficult for Mr. Olmsted to entertain the idea of returning to his work there, he wrote to Mr. Vaux from California:

But you know that the advantages offered in the office of the Superintendent for spending a good deal of my life in the park, being with the people in it, watching over it and cherishing it in every way,- - living in it and being a part of it (whatever else there was),- -were valued by me at a valuation which you thought nonsensical, childish and unworthy of me; but it was my valuation of them and not yours which was concerned. And that this was something deeper than a whim you know, for you know that it existed essentially years before it attached itself to the Central Park as was shown by the fact that while others gravitated to pictures, architecture, Alps, libraries, high life and low life when travelling, I had gravitated to parks,--spent all my spare time in them, when living in London for instance, and this with no purpose whatever except a gratification which came from sources which the Superintendence of the Park would have made easy and cheap to me, to say the least, every day of my life. What I wanted in London and in Paris and in Brussels and everywhere I went in Europe-what I wanted 
in New York in $\mathbf{1} 857$, I want now and this from no regard for Art or fame or money.

Mr. Olmsted's own summary of his fitness for the opportunity which presented itself in 1857 , he gave in Spoils of the Park, written in $\mathbf{1 8 8 2}$, to be reprinted in full in Volume Two of this work.

It is worth while also, perhaps, to give in conclusion two of the endorsements submitted with his Central Park application in I857. (See facsimile opposite.)

Similar petitions bear the signatures of Russell Sturgis, Horace Greeley, George H. Putnam, Henry Holt, Whitelaw Reid, William Cullen Bryant, Bayard Taylor, Alexander Hamilton, Philip Schuyler, John M. Scribner, August Belmont, Morris K. Jesup, Henry Havemeyer, E. D. Morgan, Roosevelt \& Co., and many others. Gray:

Pleasantest of all was the letter from Professor Asa

\section{"HARVARD UNIVERSITY \\ "Botanic Garden, August 24, I857.}

"To THE PREsident OF THE BoARd OF

COMMissioners OF THE NEW YORK PARK

"Dear Sir

"I have just learned that $F$. Law Olmsted, Esq., is about to offer himself as a candidate for the superintendency of the Central Park, New York.

"I desire very simply and sinccrely to say that I know Mr. Olmsted well, and that I regard him as eminently fitted for that position. I do not know another person so well fitted for it in all respects, both on practical and general scientific grounds and I have no doubt that if the choice falls upon him, he will do great honor to the situation and to his own already high and honorable reputation.

"I have the honor to be

with great respect

Your obedient faithful servant

"(sgd.) Asa Gray.

"Professor of Botany \&c.

"Harvard University." 


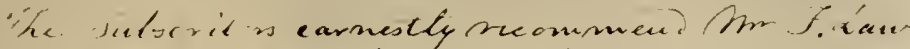

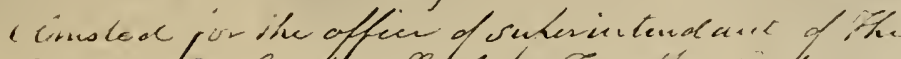

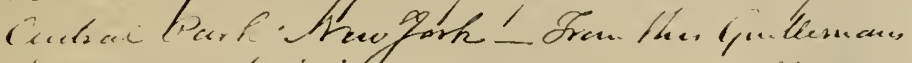
prackal training as an Agrivelluratis, Ne.

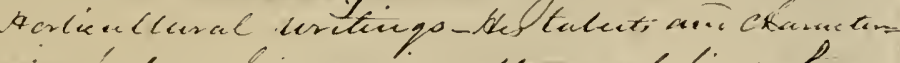

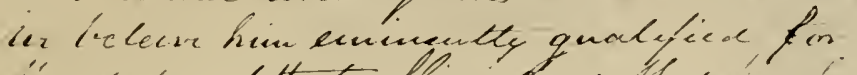
inc denles of that offece cand that fines ine

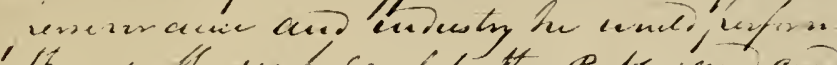

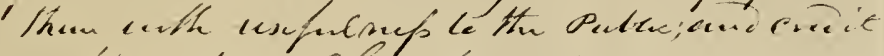

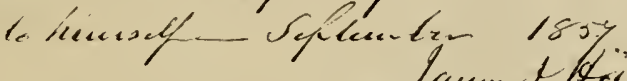

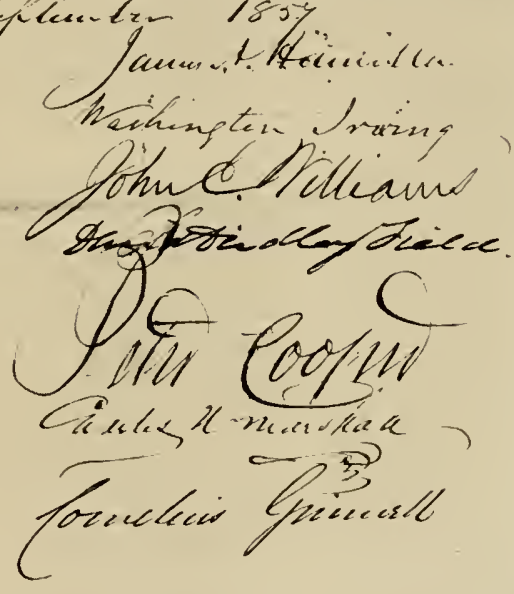

Facsimile of Petition to Secure Appointment of Mr. Olmsted as Superintendent of Central Park, I857 

PART III. AMERICAN LANDSCAPE GARDENING IN 1857 



\section{PART III}

\section{AMERICAN LANDSCAPE GARDENING IN 1857}

IN September, 1857, when Frederick Law Olmsted was appointed Superintendent of the Central Park in New York, there was no well-established profession of landscape gardening in the United States and the term landscape architect ${ }^{\mathrm{x}}$ was unknown. The untimely death of Andrew Jackson Downing had come five years earlier. It was not until the very end of 1857 that Downing's architectural associate and successor, Calvert Vaux, invited the new Superintendent of the Central Park to participate with him in the competition for the design, thus beginning a partnership which brought about public recognition of a new professional field. It is worth mentioning that the New York newspapers of the day regarded only a few of the thirty-three ${ }^{2}$ plans submitted in the competition as worth attention, and characterized many as puerile and entirely unsuitable. Of the four premiated plans, the second was submitted by Mr. Samuel I. Gustin, the superintendent of planting at the Park, the third by Messrs. Miller and McIntosh, two employees in the office of the Superintendent (Mr. Olmsted), and the fourth by an architect, Mr. Howard Daniels,-none of these gentlemen apparently enjoying any distinction in the public eye. The

× The term "Landscape Architecture" in a restricted sense (of Architecture in Landscape) was used in England by Laing Meason in I 828 as the title of a work which contained a discussion of Italian villas: The Landscape Architecture of the Great Painters of Italy. This work was referred to in a Review of Downing's Cottage Residences and two other books on landscape gardening, which appeared in the North American Review, Oct., I 844, p. 308.

2 Two more designs were submitted, but not in competition. The editors discovered in the New York Public Library a printed copy of "Catalogue of Plans for the Improvement of the Central Park" annotated by one of the Park Commissioners with the names of the supposed authors of the thirty-five sets of drawings. 
competition plan of Colonel Viele, Chief Engineer, whose original design for the Park had been rejected before the institution of the competition, found no favor with the commissioners. Mr. Ignaz A. Pilat, an Austrian, said to have designed the grounds of Prince Metternich, and who had been engaged since I 856 on a botanical survey of the ground of the Central Park, submitted a design, although not in competition. It would appear that no distinguished foreign designer participated, although the Central Park Commissioners had hoped for this, and had gone so far as to appropriate money for the traveling expenses of the "engineers or other persons in chief" by whom the Bois de Boulogne and Birkenhead Park had been laid out and constructed, could they be induced to visit New York for the purpose of giving the Board "aid and information."

At this time in Boston the firm of Copeland and Cleveland (R. Morris Copeland and H. W. S. Cleveland) was engaged in the professional practice of landscape gardening, mainly the laying-out of suburban and country estates. In I856 these gentlemen had published a very sensible pamphlet modestly entitled $A$ Few Words on the Central Park, in which they urged on the City of New York the ultimate economy of a comprehensive plan. Mr. Charles Follen, also of Boston, was in practice at the time, styling himself "architect and landscape gardener," in his pamphlet, Suggestions, intended for estate owners, issued in I859. Both Mr. Copeland and Mr. Follen submitted plans in the Central Park competition.

In a book published at Cincinnati early in $\mathbf{1} 855$, called Practical Landscape Gardening, the author, G. M. Kern, refers to a flourishing state of the art of laying out grounds in the Mississippi region and mentions especially Adolph Strauch, of Cincinnati, now remembered as the designer of Spring Grove Cemetery, which he undertook in that same year, I855. But the field in the West as in the East was mainly restricted to private grounds, and the "many representatives" mentioned by Mr. Kern remained obscure, most of them perhaps landschaftsgärtner emigrated from Europe with the influx of German settlers to the Middle West at this period.

Outside of Downing's writings, which were widely known, there were few books on landscape gardening by American writers, and few English books had gone into American editions. Even in I860, Mr. C. A. Dana, as editor of Appleton's 


\section{American Landscape Gardening}

New American Cyclopedia, wrote to Mr. Olmsted, from whom Mr. Dana was soliciting an article on the title Park: "It is curious that no Cyclopedia has an article on Parks or Landscape Gardening;" remarking also: "We have no article, nor is there in any part of the work, as yet, anything bearing on that subject. Under Downing we give a simple biography of the man and a list of his principal works."

Mr. Olmsted frequently commented, in contrast, on the advancement of the profession of landscape gardening in Europe. In his article for Appleton's Cyclopedia, we find several passages, quite as true in 1857 as in 1861 when they were published, bearing on this point:

Almost every large town in the civilized world now has public pleasure grounds in some form. . . .

Birkenhead park [which Mr. Olmsted had visited in $\left.185^{\circ}\right]^{\mathrm{x}}$ is a piece of ground of $\mathbf{I} 85$ acres in a suburb of Liverpool, and is surrounded by villas the grounds of which connect with it. Though small, it is by its admirable plan the most complete, and for its age the most agreeable park in Europe. It was designed and its construction superintended by Sir Joseph Paxton and Mr. Kemp. . . .

In the United States there is, as yet, scarcely a finished park or promenade ground deserving mention. In the few small fields of rank hay grasses and spindle-trunked trees, to which the name is sometimes applied, the custom of the promenade has never been established. Yet there is scarcely a town or thriving village in which there is not found some sort of inconvenient and questionable social exchange of this nature. Sometimes it is a graveyard, sometimes a beach or wharf, sometimes a certain part of a certain street; sometimes interest in a literary or a charitable, a military, or even a mercantile enterprise, is the ostensible object which brings people together. But in its European signification the promenade exists only in the limited grounds attached to the capitol and to the "white house" at Washington, and in the yet half-made park of New York. . . .

See p. 95 . 
Landscape gardening in the United States ${ }^{\mathrm{I}}$ has hitherto been chiefly directed to the improvement of naturally wooded scenery, and that on a small scale, yet in many instances, of which the best are on the banks of the Hudson, with admirable results. Publicly the art has been chiefly directed, also, to the improvement of naturally wooded picturesque scenery in the formation of rural cemeteries.

Turning from an analysis of the actual condition of the landscape art, Mr. Olmsted mentions certain sources of inspiration:

In the various Picturesque Tours of Gilpin, and the voluminous Essays on the Picturesque by Sir Uvedale Price, the true principles of art applicable to the creation of scenery were laboriously studied and carefully defined. Shenstone, Mason and Knight, by their poems, materially aided the revivification of the art. In more recent times the good service of Repton, Loudon, Paxton, Kemp, our own Downing, and other artists and writers on the subject during the present century merits warm acknowledgment. Downing's works especially should be in every village school library.

A horticultural atmosphere pervaded the landscape work of I 857. Downing's Horticulturist, as its name implies, had up to his death served not only as his own mouthpiece but also a medium of communication for the many cultivated gentlemen who were apt to prefer interesting specimen plants to picturesque compositions. Downing himself ran a nursery and reflected to a less degree the taste of the period for a horticultural style. That conditions in the United States were in general scarcely different thirty years later shows against what odds the new profession had to make headway. Writing in I 888 to one of a board of park commissioners in Rochester, Mr. Olmsted might almost equally

$\therefore$ Mr. Olmsted does not mention the work of M. Andre Parmentier, of Brooklyn, whom Downing considered of great importance (see Downing's Theory and Practice of Landscape Gardening, 184I), and several other earlier amateur and professional landscape gardeners, especially in Virginia and Pennsylvania. 


\section{American Landscape Gardening}

have been addressing a commissioner of 1858 , had there been park boards at that time outside of New York City.

With reference to your undertaking there is less room for choice than may be supposed among the landscape gardeners or landscape architects of the country. (I have come to prefer the latter term, tho' I much objected to it when it was first given me. I prefer it because it helps to established the important idea of the distinction of my profession from that of gardening, as that of architecture from building-the distinction of an art of design.)

Of those who have given themselves the title of landscape gardeners not one of many more than a hundred have the smallest right to it. As a rule they are further from it than the average citizen of fair general education. This because the most of them have passed the best educational years of their lives in close and toilsome confinement to matters horticultural, botanical and on a small scale decorative, pursuing a course in this and other respects in which faculties of close observation and handicraft skill are cultivated. A course in fact such as you might prescribe for a patient whom you wished to wean from too great susceptibility to and interest in grasses, bushes and trees as components of natural scenery. The gardening to which they apply the term landscape is just that, in its essence, which the term landscape gardening was first used as a means to rule out of view.

Hamerton in his treatise of Landscape says that "scape" in this word was from the same root and properly has the same significance with ship, e. g. in friendship-meaning, that is to say, the comprehensive state, to the eye, of the land or region to which it is applied. (I should rather say the character, broadly considered, of the scenery of a region.) Of late the training of gardeners has been not at all to landscape in this sense but to elements, incidents and features of the materials of landscape considered by themselves; to make 
them artists possibly in a certain way, as an ordinary house furnisher may be trained to something of art in respect to articles of furniture, pictures, books and bric-à-brac, but not artists in respect to scenery, as scenery acts in the emotional nature of some of us. That a training which is innocently assumed to be a training in landscape gardening is a training in fact away from it, I have often seen evidences. For example, a man came to me with a letter of introduction in which it was stated that he was a landscape gardener. As the best feast that I could offer a visitor of this description fresh from the old world, I dropped my business for a day to take him up the Hudson. It was soon apparent that he took less than ordinary interest in its natural scenery. When we came near to the best of it I had to urge him to move to a position on the boat where he could see it. Having done so, in a minute or two he left it, and when near West Point, I found him below sitting at a table with a bottle of porter. Yet when I took him to the grounds of a friend's country-seat he proved to be really an enthusiast in particular matters of gardening.

I have seen much of two of the most accomplished gardeners in the United States but I never saw either of them look at anything a stone's throw away or show the slightest interest in or understanding of landscape. There is nothing to prevent them from presenting themselves in good faith as landscape gardeners. In conversing with one previously called a florist but who had offered himself and been appointed landscape gardener of an important work, I found that he applied the term 'harmony,' with reference to the grouping of trees, on the supposition that it meant botanical kinship. In the gap between two masses of fine indigenous foliage he had planted some Chinese curios not only in complete discord with them but where, if they lived long, they would screen off his finest distant view.

Even of landscape gardening rightly so called, the practice of most has been at best upon small grounds or upon 


\section{American Landscape Gardening}

grounds in which the convenience and probable wants of but a single family and its selected guests were to be considered, a good design for which is a very different thing from good design for grounds in which the movements of many thousands are to be provided for and precautions taken not only against careless and erratic movements but against occasional malevolent torrents of a disorderly rabble.

Of the thirty-four plans of so many assumed landscape gardeners offered to Commissioners of the Central Park in I 857, but one made the slightest provision for requirements which everyone now sees it was absolutely necessary should be provided for. If any one of the others had been adopted an almost complete reconstruction of the Park would before this time have been necessary. Among the plans offered, that which, from the opportunities and well-earned reputation of the planner, I had expected to be the best, aimed at nothing more than a connected and diversified series of effects appropriate to confined private suburban pleasure grounds.

Of twenty-two plans obtained ten years ago by the Boston Park Commissioners-several of which had cost the planners over a thousand dollars each, and were most painstakingly studied-even that which they adjudged to be the best was after a few months entirely abandoned. (They finally came to me for a plan which when published was bitterly denounced, declared publicly, by an alleged landscape gardener of large experience, wholly impracticable and so held up to scorn that an association of citizens-large property holders - privately employed a civil engineer to professionally examine and report upon it. It has been carried out with no essential variation and all objections have fallen to the ground.)

I have written all the foregoing to justify the opinion I now give you that in all Europe and America, among all the men who with no dishonest intention take the name of landscape gardeners (or architects) there are very few who have 
shown or are likely to possess any respectable power of dealing with problems of the class that properly come before the Park Commissioners of a large and growing city.

Of those among them likely to be available to you the man of highest proved ability is my old partner Calvert Vaux of New York. There are respects of design in which he is probably the superior of any living man. . . . There are in the country to my knowledge but two other (properly speaking) landscape designers who have had any experience that would specially qualify them to advise you.

One of them is H. W. S. Cleveland. He is a cultivated Boston born and bred man, has been employed in responsible positions on the public parks of Brooklyn, Chicago and Minneapolis. He is the oldest landscape gardener in the country. . .

The other is J. Weidenmann, the author of a book published by the Appletons ${ }^{\mathrm{I}}$ on landscape gardening; a Swiss by birth. He laid out and superintended for years, the public park at Hartford, Conn. . . .

No doubt there are other promising men whom I don't know or think of, for the profession is not organized and every man fights on his own hook.

There are three or four men who tell fine stories of themselves as landscape gardeners, even in some cases showing what appear to be reputable testimonials, whom I should like to caution you against but I do not feel quite justified in mentioning them by names. One, an Englishman, I have good reason to believe a knave. Another, a clever young fiddler, comes from the north of Europe originally, later from Paris. Another has published a pamphlet on Landscape Gardening in which he aims to appear a man of Science and shows himself a hopeless ignoramus.

I Mr. Olmsted must have meant Beautifying Country Homes, published by the Orange Judd Company. 


\section{American Landscape Gardening I3I}

If there were fewer pretenders to the landscape art in I 857, there was also an even less developed public taste, and Mr. Olmsted could scarcely have been precipitated into a field where his already recognized talent of literary expression could have joined to greater advantage with his appreciation of scenery, his latent genius as an artist, and his knowledge as a practical farmer. 



\section{A Journey \\ in the Back Country in the Year 1854}

\section{By \\ Frederick Law 0lmsted}

Author of "A Journey in the Seaboard Slave States," etc.

(Originally issued in 1860.) 2 Volumes. 800.

Readers for entertainment will be fascinated by this vivid portrayal of the picturesque ideas, customs, and manners of Southerners before the Civil War. Students of history will find no more reliable or more abundant record of observations on Southern social conditions, especially negro slavery.

\section{G. P. Putnam's Sons}

New York

London 


\section{A Work of Distinction \\ A Journey in the Seaboard Slave States

\author{
$1853=1854$
}

With Remarks on Their Economy

By

\section{Frederick Law 0lmsted}

Author of "Walks and Talks with an American

Farmer in New England"

With a Biographical Sketch by

Frederick Law Olmsted, Jr.

and an Introduction by W. P. Trent

Second Edition. 2 Vols., with Portrait. Octavo

Although published nearly fifty years ago, the work today is not only valuable, but is intensely interesting reading. It depicts the horrors of slavery, and this is done in calm judicial manner. It is in no degree sensational, but presents the facts as seen or heard from credible witnesses, and is invaluable to students of the causes of the Civil War.

"The reader who cares to understand the Civil War should read the narrative by Frederick Law Olmsted entitled 'A Journey in the Seaboard Slave States.' Mr. Olmsted's volumes present as interesting a picture of the South before its great catastrophe as is given by Arthur Young of France on the eve of its revolution."

-Morley's Life of Gladstone.

\section{G. P. Putnam's Sons}







